\title{
Vanadium(IV/V) complexes of Triapine and related thiosemicarbazones: synthesis, solution equilibrium and bioactivity
}

\author{
Christian R. Kowol ${ }^{\mathrm{a}, b^{*}}$, Nóra V. Nagy ${ }^{\mathrm{c}}$, Tamás Jakusch ${ }^{\mathrm{d}}$, Alexander Roller ${ }^{\mathrm{a}}$, Petra \\ Heffeter $^{\text {b,e }}$, Bernhard K. Keppler ${ }^{a, b}$, Éva A. Enyedy ${ }^{d^{*}}$ \\ ${ }^{a}$ University of Vienna, Institute of Inorganic Chemistry, Währinger Strasse 42, A-1090 Vienna, Austria. \\ ${ }^{\mathrm{b}}$ Research Platform “Translational Cancer Therapy Research" University of Vienna, Waehringer Strasse 42, A- \\ 1090, Vienna, Austria. \\ ${ }^{\mathrm{c}}$ Institute of Organic Chemistry, Research Centre for Natural Sciences, Hungarian Academy of Sciences, \\ Magyar Tudósok körútja 2., H-1117 Budapest, Hungary. \\ ${ }^{\mathrm{d}}$ Department of Inorganic and Analytical Chemistry, University of Szeged, H-6720 Szeged, Hungary. \\ ${ }^{\mathrm{e}}$ Institute of Cancer Research and Comprehensive Cancer Center, Medical University of Vienna, Borschkegasse \\ 8a, A-1090, Vienna, Austria.
}

Keywords: Equilibria; Cytotoxicity; Stability constants; X-ray crystal structure; EPR spectroscopy

\section{ABSTRACT}

The stoichiometry and thermodynamic stability of vanadium(IV/V) complexes of Triapine and two related $\alpha(\mathrm{N})$-heterocyclic thiosemicarbazones (TSCs) with potential antitumor activity have been determined by $\mathrm{pH}$-potentiometry, EPR and ${ }^{51} \mathrm{~V}$ NMR spectroscopy in $30 \%$ (w/w) dimethyl sulfoxide/water solvent mixtures. In all cases, mono-ligand complexes in different protonation states were identified. Dimethylation of the terminal amino group results in the formation of vanadium(IV/V) complexes with considerably higher stability. Three of the most stable complexes were also synthesized in solid state and comprehensively characterized. The biological evaluation of the synthesized vanadium complexes in comparison to the metal-free ligands in different human cancer cell lines revealed only minimal influence of the metal ion. Thus, in addition the coordination ability of salicylaldehyde thiosemicarbazone (STSC) to vanadium(IV/V) ions was investigated. The exchange of the pyridine nitrogen of the $\alpha(\mathrm{N})$-heterocyclic TSCs to a phenolate oxygen in STSC significantly increased the stability of the complexes in solution. Finally, this also resulted in increased cytotoxicity activity of a vanadium(V) complex of STSC compared to the metal-free ligand.

\footnotetext{
* Corresponding authors. Fax: +36 62 544340; +43 1427752680.
} 
E-mail addresses: enyedy@chem.u-szeged.hu (É.A. Enyedy); christian.kowol@univie.ac.at (C.R. Kowol).

\section{Introduction}

Thiosemicarbazones (TSCs) are Schiff bases obtained by condensation of an aldehyde or a ketone with a thiosemicarbazide and represent an important class of $(\mathrm{N}, \mathrm{S})$ donor ligands [1]. TSCs and their metal complexes are extensively investigated as they exhibit a wide range of pharmacologically interesting properties like anticancer, antibacterial, antiparasitic, and antiviral effects [2]. Especially $\alpha(\mathrm{N})$-heterocyclic TSCs exert significant antitumor activity in vitro and in vivo [2,3]. Triapine (3-aminopyridine-2-carbaldehyde thiosemicarbazone, 3-AP, Chart 1) is the most prominent representative among the $\alpha(\mathrm{N})$-pyridyl TSCs since it has already been tested in many phase I and II clinical trials [4]. The proposed mechanism of action of Triapine is based on its ability to inhibit the iron-dependent enzyme ribonucleotide reductase, the rate-determining enzyme in the supply of deoxyribonucleotides for DNA synthesis and repair [3,5]. It has been assumed that the formation of an intracellular iron complex of Triapine plays a crucial role in the mechanism of enzyme inhibition [6]. In this complex, Triapine acts as tridentate ligand and coordinates via an $\left(\mathrm{N}_{\mathrm{pyr}}, \mathrm{N}, \mathrm{S}^{-}\right)$donor set, wherein the hydrazinic-N moiety is deprotonated [3]. In general, this arrangement of the donor atoms for $\alpha(\mathrm{N})$-pyridyl TSCs is also suitable for the binding of other transition metal ions, e.g. $\mathrm{Cu}(\mathrm{II}), \mathrm{Zn}(\mathrm{II}), \mathrm{Ru}(\mathrm{III}), \mathrm{Pt}(\mathrm{II})$, and $\mathrm{Pd}(\mathrm{II})$, which can result in complexes with even higher cytotoxicity than that of the metal-free ligands [2]. In our previous works we pointed out that dimethylation of the terminal nitrogen strongly enhances the cytotoxicity of $\alpha(\mathrm{N})$ pyridyl TSCs, especially in the absence of any $\mathrm{NH}_{2}$ group in the molecule [7]. In addition, terminal dimethylation results in a strong increase of the solution stability of the $\mathrm{Fe}(\mathrm{II} / \mathrm{III})$, $\mathrm{Cu}(\mathrm{II}), \mathrm{Zn}(\mathrm{II})$, and $\mathrm{Ga}(\mathrm{III})$ complexes [7-9]. The best-known terminally dimethylated bispyridyl TSC is di-2-pyridylketone-4,4-dimethyl-3-thiosemicarbazone (Dp44mT), which demonstrated very potent anticancer activity in vivo using human xenografts in nude mice $[10,11]$ and was reported to overcome multidrug-resistance in cancer cells [12].

In addition, to the effects of the free ligands, also a wide range of metal complexes of tridentate TSCs with remarkable biological effect has been reported in the literature including copper [13-15], platinum [16], or vanadium compounds $[2,17,18]$. With regards to vanadium, complexes of $\alpha(\mathrm{N})$-pyridyl TSCs formed with oxovanadium(IV) and dioxovanadium(V) were 
found to exert antibacterial, antifungal as well as antiamoebic activity [17-20]. In addition, insulin-enhancing properties of some $\mathrm{V}(\mathrm{V}) \mathrm{O}_{2}-\mathrm{TSC}$ complexes have been reported [21]. However, the antitumor properties of $\alpha(\mathrm{N})$-pyridyl TSC vanadium complexes have, to the best of our knowledge, not been investigated so far. Moreover, despite the fact that a relatively large number of vanadium(IV/V) complexes of TSCs has been synthesized and characterized in the solid state or in solution with organic solvents [19-24], almost no information is available on their complex formation processes and thermodynamic stability in aqueous solution. Notwithstanding, the knowledge of the speciation and the most feasible chemical forms of a biologically active metal complex in aqueous solution, especially at physiological $\mathrm{pH}$, can help to understand the mechanism of action and might be useful for the design of more effective and selective chemotherapeutics. Thus, the main aims of the present work were to perform a detailed solution equilibrium study on the vanadium(IV/V) complexes of Triapine and two terminally dimethylated derivatives (Chart 1, 3-aminopyridine-2carboxaldehyde N,N-dimethylthiosemicarbazone (APTSC) and pyridine-2-carboxaldehyde $\mathrm{N}, \mathrm{N}$-dimethylthiosemicarbazone (PTSC)), and to screen their cytotoxicity against human cancer cell lines. Therefore, various methods such as pH-potentiometry, UV-vis spectrophotometry as well as electron paramagnetic resonance (EPR) and ${ }^{51} \mathrm{~V}$ NMR spectroscopy were used to investigate the stoichiometry and stability of the complexes in solution. Additionally, several vanadium complexes were synthesized and subsequently characterized by means of ${ }^{1} \mathrm{H},{ }^{13} \mathrm{C}$, and ${ }^{51} \mathrm{~V}$ NMR spectroscopy as well as X-ray diffraction studies. Finally, the obtained solution speciation data of the vanadium(IV/V) complexes formed with $\alpha(\mathrm{N})$-pyridyl TSCs were compared to that of salicylaldehyde thiosemicarbazone (STSC, Chart 1) complexes with an $\left(\mathrm{O}^{-}, \mathrm{N}, \mathrm{S}^{-}\right)$donor set.

Chart 1

\section{Results and Discussion}

2.1. Solution chemistry of vanadium(IV/V) complexes of Triapine, APTSC, and PTSC

\subsection{1. $p K_{a}$ values and lipophilicity of the ligands}

The proton dissociation constants $\left(\mathrm{p} K_{\mathrm{a}}\right)$ of Triapine, APTSC and PTSC (Table 1$)$ in a $30 \%(\mathrm{w} / \mathrm{w}) \mathrm{DMSO} / \mathrm{H}_{2} \mathrm{O}$ solvent mixture were already determined in our previous work by 
pH-potentiometric, UV-vis, and ${ }^{1} \mathrm{H}$ NMR titrations [8]. In accordance to these data, the repetitive measurements in this study provided similar values. Noteworthy, the presence of DMSO was required due to the limited water solubility of the ligands as well as their respective vanadium complexes. The obtained $\mathrm{p} K_{1}$ can be attributed to the proton dissociation of the pyridinium unit and $\mathrm{p} K_{2}$ values to the deprotonation of the hydrazinic $\mathrm{NH}$ group of the thiosemicarbazide moiety. In the latter proton dissociation step, the resulting negative charge is mainly localized on the $\mathrm{S}$ atom via the thione-thiol tautomeric equilibrium (Chart 2) [8]. Based on the $\mathrm{p} K_{\mathrm{a}}$ values, it can be concluded that all three $\alpha$-pyridyl TSCs are present in their neutral HL form at $\mathrm{pH} 7.4$.

\section{Table 1, Chart 2}

In order to characterize the lipophilic character of the ligands, distribution coefficients of APTSC and PTSC were determined by the traditional shake flask method at $\mathrm{pH} 7.4$ $\left(\log D_{7.4}\right.$ values in Table 1$)$, which represent the actual partitioning between $n$-octanol and water. As expected, the methyl groups on the terminal nitrogen of the $\alpha$-pyridyl TSCs increase the $\log D_{7.4}$ value compared to that of the reference compound Triapine [25].

\subsubsection{Complex formation equilibria of vanadium(IV) with Triapine, APTSC, and PTSC}

The complex formation processes of Triapine, APTSC, and PTSC with V(IV)O were studied by the combined approach of pH-potentiometry, UV-vis spectrophotometry, and EPR spectroscopy in a $30 \%(\mathrm{w} / \mathrm{w}) \mathrm{DMSO} / \mathrm{H}_{2} \mathrm{O}$ solvent mixture under anaerobic conditions. The stoichiometries of the oxovanadium(IV) complexes and the overall stability constants calculated on the basis of the $\mathrm{pH}$-potentiometric titrations are listed in Table 1. These studies revealed formation of mono-ligand complexes such as $[\mathrm{V}(\mathrm{IV}) \mathrm{O}(\mathrm{L})]^{+}$and $\left[\mathrm{V}(\mathrm{IV}) \mathrm{O}\left(\mathrm{L}_{)}\right) \mathrm{H}_{-1}\right]$. Although, other bivalent metal ions (e.g. $\mathrm{Zn}(\mathrm{II})$ and $\mathrm{Fe}(\mathrm{II})$ ) form $[\mathrm{M}(\mathrm{LH})]^{2+}$ species as well [8], stability constants for this kind of V(IV)O complexes could not be calculated with appropriate accuracy. Complexation of Triapine with V(IV)O starts only at $\mathrm{pH}>4$ and the ligand is not able to protect the metal ion against the hydrolysis at a metal-to-ligand ratio of $1: 1$ at $\mathrm{pH}>6$ in the $1 \mathrm{mM}$ concentration range resulting in precipitation. Notably, a maximum of $20 \%$ of $\mathrm{V}(\mathrm{IV}) \mathrm{O}$ is bound to Triapine (at $\mathrm{pH} \sim 5$ under this condition) representing a quite weak metal-binding ability of this ligand (Fig. 1a). On the contrary, complex formation processes with the terminally dimethylated ligands (PTSC and APTSC) start at lower pH values $(\mathrm{pH} \sim 2-2.5)$ indicating species of higher stability. In addition, the bound fraction of oxovanadium(IV) exceeds $90 \%$ at $\mathrm{pH} \sim 5.2$ and 4.5 in the V(IV)O - APTSC and PTSC 
systems, respectively (Figs. 1b and c). Complex formation in the V(IV)O - PTSC system was also monitored by UV-vis spectrophotometric titrations. Instead of the rather weak $d-d$ transition bands of the complexes, the $\mathrm{pH}$-dependence of the overlapping charge-transfer (CT) and ligand bands was followed. Differences between the absorbance values recorded in the presence and in the absence of the $\mathrm{V}(\mathrm{IV}) \mathrm{O}$ ions undoubtedly reveal the $\mathrm{pH}$ ranges of the complex formation followed by dissociation. This corresponds well to the expectations based on the concentration distribution curves calculated with the aid of the stability constants (Fig. S1).

\section{Figure 1}

In order to elucidate the actual coordination modes in solution and confirm the speciation model obtained by $\mathrm{pH}$-potentiometry, EPR spectra were recorded at various $\mathrm{pH}$ values at room temperature (Fig. 2). In case of the V(IV)O - PTSC system, spectra could be recorded up to $\mathrm{pH} 9.8$ using individual samples. In contrast, when titrations were performed with Triapine and APTSC, oxidation took place resulting in the continuous loss of the EPR signal at higher $\mathrm{pH}$ values, although the measurements were done under an argon atmosphere (but not under strictly anaerobic conditions). It is noteworthy, that the hydrolysis of the metal ion can strongly increase the sensitivity to oxidation. The two-dimensional simulation of the solution EPR spectra resulted in the individual isotropic EPR spectra (Fig. 2) and the isotropic EPR parameters of V(IV)O and the complexes [V(IV)O(L) $]^{+}$and $\left[\mathrm{V}(\mathrm{IV}) \mathrm{O}(\mathrm{L}) \mathrm{H}_{-1}\right]$ (Table 2). There was no indication for formation of EPR-active dinuclear or bis-ligand complexes. Similar $g_{0}$ and $A_{0}$ values were obtained for all $[\mathrm{V}(\mathrm{IV}) \mathrm{O}(\mathrm{L})]^{+}$complexes of the different $\alpha$ pyridyl TSCs, in which the tridentate coordination of the ligands via the $\left(\mathrm{N}_{\text {pyr }}, \mathrm{N}^{2}, \mathrm{~S}^{-}\right)$donor set is the most probable (Chart 3) and where the ligand possesses a deprotonated hydrazinic moiety. In comparison, formation of isomers and somewhat higher $A_{0}$ parameters $\left(94.7 \times 10^{-4}\right.$ $\mathrm{cm}^{-1}$ and $101 \times 10^{-4} \mathrm{~cm}^{-1}$ ) were reported for chlorido V(IV)O-thiosemicarbazone complexes in a non-aqueous solvent [26]. Complexes $\left[\mathrm{V}(\mathrm{IV}) \mathrm{O}(\mathrm{L}) \mathrm{H}_{-1}\right]$ have higher $g_{0}$ values and lower $A_{0}$ values compared to those of $[\mathrm{V}(\mathrm{IV}) \mathrm{O}(\mathrm{L})]^{+}$indicating an increased ligand field due to the deprotonation of the coordinated water molecule. As a consequence, [V(IV)O(L) $\mathrm{H}_{-1}$ ] complexes are considered as mixed hydroxido species $[\mathrm{V}(\mathrm{IV}) \mathrm{O}(\mathrm{L})(\mathrm{OH})]$. Using the empirical additivity relationship [27,28], the average $A_{0}$ value of the contribution of a thiolate, two aromatic nitrogen atoms (no data for imine-N) and a water molecule is $87.0 \times 10^{-4} \mathrm{~cm}^{-1}$ and for the mixed hydroxido species $80.6 \times 10^{-4} \mathrm{~cm}^{-1}$. All estimations are in good agreement with the measured data in Table 2.

Figure 2, Table 2 
In the case of the V(IV)O - PTSC system, EPR spectra were also recorded on frozen samples at $77 \mathrm{~K}$. The calculated anisotropic EPR parameters (Table 3) and the spectra simulation for the $[\mathrm{V}(\mathrm{IV}) \mathrm{O}(\mathrm{L})]^{+}$and $\left[\mathrm{V}(\mathrm{IV}) \mathrm{O}(\mathrm{L}) \mathrm{H}_{-1}\right]$ species (Fig. 3) permitted the conclusion that most probably two kinds of isomers with a molar ratio of $\sim 1: 6$ are formed under these conditions. The isotropic EPR parameters of the major isomers (1) calculated by averaging the anisotropic values $\left(g_{0, \text { calc }}\right.$ and $A_{0, \text { calc }}$ in Table 3$)$ are similar to those of the data measured at room temperature showing that the structure of the complexes $[\mathrm{V}(\mathrm{IV}) \mathrm{O}(\mathrm{L})]^{+}$and $\left[\mathrm{V}(\mathrm{IV}) \mathrm{O}(\mathrm{L}) \mathrm{H}_{-1}\right]$ did not change during freezing. On the other hand, the minor isomers (2) have fairly different anisotropic EPR parameters, which can be possibly explained by the octahedral "trans" $\left(\mathrm{H}_{2} \mathrm{O}\right.$ : axial, PTSC: equatorial, equatorial, equatorial, $\mathrm{H}_{2} \mathrm{O} / \mathrm{OH}^{-}$equatorial) penta-coordinated square pyramidal or octahedral "trans" - octahedral "cis" $\left(\mathrm{H}_{2} \mathrm{O}\right.$ : equatorial, PTSC: equatorial, axial, equatorial, $\mathrm{H}_{2} \mathrm{O} / \mathrm{OH}^{-}$equatorial) - isomerism [29], which is quite frequent in the case of $\mathrm{V}(\mathrm{IV}) \mathrm{O}$ species and was also observed for other $\mathrm{V}(\mathrm{IV}) \mathrm{O}$ - TSC complexes $[24,26]$. In the protonation state of VO(IV)L the octahedral "trans", while in the case of complex [V(IV)OL(OH)] the penta-coordinated / octahedral "cis" forms are the most stable species.

\section{Table 3, Figure 3}

Direct comparison of stability constants and concentration distribution curves calculated for the V(IV)O complexes formed with the $\alpha$-pyridyl TSCs (Table 1, Fig. 1) shows that Triapine is hardly able to form stable complexes with $\mathrm{V}(\mathrm{IV}) \mathrm{O}$ even at $\mathrm{mM}$ concentrations. In contrast, the complex stability of terminally dimethylated TSCs is distinctly increased. This is in good agreement with previous studies from our group on other metal ions $[8,9]$.

\subsubsection{Complex formation equilibria of vanadium(V) with Triapine, APTSC, and PTSC}

As a next step, the V(V)-binding abilities of Triapine, APTSC, and PTSC were studied by ${ }^{51} \mathrm{~V}$ NMR spectroscopy. This method provides an excellent possibility to distinguish between the free $\mathrm{V}(\mathrm{V})$ species (in monomeric or different oligomeric forms) and $\mathrm{V}(\mathrm{V})$ complexes due to the slow ligand-exchange process with respect to the NMR time scale. Therefore, signals of bound and free metal ions can be seen separately (as an example, PTSC is shown in Figs. 4.a). However, species with the same metal-to-ligand ratio in different protonation states represent fast exchange processes. Thus, their signals are only shifted upon the (de)protonation processes. First of all, complex formation was followed at $\mathrm{pH} 7.4$ in the 
$1.0 \mathrm{mM}$ concentration range. No bound $\mathrm{V}(\mathrm{V})$ fractions were found in the case of Triapine as a consequence of the quite low vanadate affinity of this ligand. Accordingly, further measurements were only performed for APTSC and PTSC.

\section{Figure 4}

${ }^{51} \mathrm{~V}$ NMR spectra were recorded in the $\mathrm{pH}$ range $11.2-\sim 1.6$ by the addition of strong acid to the samples, although an irreversible process was observed at $\mathrm{pH}<5$ and the intensities of the peaks were strongly diminished. Most probably $\mathrm{V}(\mathrm{V})$ is able to oxidize APTSC and PTSC in this $\mathrm{pH}$ range with simultaneous formation of paramagnetic $\mathrm{V}(\mathrm{VI}) \mathrm{O}$. Interestingly, a similar redox reaction was already described for $\mathrm{Fe}(\mathrm{III})$ complexes of $\alpha(\mathrm{N})$ pyridyl TSCs, however only at $\mathrm{pH}>10$ [9,30]. Solely peaks of the non-bound V(V) species could be observed at $\mathrm{pH}>\sim 10$, in the case of PTSC (Fig. 4.a) and APTSC, mainly in form of $\mathrm{HVO}_{4}{ }^{2-}$. Formation of $\left[\mathrm{V}(\mathrm{V}) \mathrm{O}_{2}(\mathrm{~L})\right]$ was further investigated with decreasing $\mathrm{pH}$ and the position of its signal in the NMR spectra did not change down to $\mathrm{pH} \sim 5$. In this complex, most probably coordination of two oxo groups and the deprotonated ligand through the $\left(\mathrm{N}_{\mathrm{pyr}}, \mathrm{N}^{2}, \mathrm{~S}^{-}\right)$donor atoms results in a distorted square-pyramidal geometry (Chart 3). This coordination mode was also confirmed by X-ray crystal structure analysis of solid V(V) PTSC and V(V) - APTSC complexes (Section 2.2). Subsequently, the distribution of V(V) between bound and unbound fractions at a 1:1 metal-to-ligand ratio was calculated on the basis of the integrated area of the peaks for the V(V) - PTSC and APTSC systems (Fig. 4.b). From these values, stability constants were computed for the formation of $\left[\mathrm{V}(\mathrm{V}) \mathrm{O}_{2}(\mathrm{~L})\right]$ complexes (see Table 4 for the equilibrium processes and constants). The bound V(V) fraction is slightly higher for PTSC compared to APTSC (91\% vs. 82\%), and the bound metal ion fraction is higher in the case of the $\mathrm{V}(\mathrm{V})$-containing systems compared to $\mathrm{V}(\mathrm{IV}) \mathrm{O}$ representing a somewhat higher stability of the $\mathrm{V}(\mathrm{V})$ complexes.

Table 4

\subsection{Synthesis and characterization of vanadium(IV/V) complexes of PTSC and APTSC}

As a result of the solution equilibrium studies, it was concluded that Triapine is not an efficient chelator for vanadium(IV/V) ions. Therefore, we prepared only the vanadium complexes of the terminally dimethylated ligands (PTSC and APTSC) for further biological studies. The two metal-free ligands APTSC and PTSC were synthesized according to literature [7,31]. The $\mathrm{V}(\mathrm{V}) \mathrm{O}_{2}$-containing complexes were synthesized in methanol in 1:2 molar ratio using the appropriate TSC ligand (HL) and the vanadium(V) precursor 
$\mathrm{V}_{2} \mathrm{O}_{4}(\mathrm{acac})_{2}$ (where acac $=$ acetylacetonate) [32]. This results in formation of the orange and red $\left[\mathrm{V}(\mathrm{V}) \mathrm{O}_{2}(\mathrm{~L})\right]$ complexes of PTSC (1a) and APTSC (1b), respectively, in good yields (Chart 3). The green oxovanadium(IV) complex [V(IV)O(L)(acac)] of PTSC (2a) (Chart 3) was synthesized in ethanol in 78\% yield using $\mathrm{VO}(\mathrm{acac})_{2}$ and the ligand in a 1:1 molar ratio.

The ${ }^{1} \mathrm{H}$ NMR spectrum of the $\mathrm{V}(\mathrm{V}) \mathrm{O}_{2}$ complexes confirmed deprotonation of the TSC ligands by absence of the $\mathrm{NH}$ proton signal of the thiosemicarbazide moiety. Furthermore, in contrast to the metal-free PTSC, which shows two isomeric forms [33] in DMSO- $d_{6}$, the $\mathrm{V}(\mathrm{V}) \mathrm{O}_{2}$ complexes possess only one set of signals in the ${ }^{1} \mathrm{H}$ NMR spectra. This can be explained by stabilization of the ligand configuration upon coordination to the metal center. The ${ }^{51} \mathrm{~V}$ NMR shifts of $\mathbf{1 a}$ at -427.5 and $\mathbf{1 b}$ at $-430.0 \mathrm{ppm}$ measured in DMSO- $d_{6}$ were in the expected range of this type of vanadium complexes [21].

Single crystals of X-ray diffraction quality of $\mathbf{1 a}$ were obtained after several days directly from the mother liquor. In contrast, crystals of $\mathbf{2 a}$ were produced by slow diffusion of ether into a solution of the complex in $\mathrm{CH}_{2} \mathrm{Cl}_{2}$ under argon atmosphere. Crystal data, data collection parameters, and structure refinement details are given in Table S1. The results of the X-ray diffraction studies are shown in Fig. 5 and selected bond distances and angles are summarized in Table 5 for $\mathbf{1 a}$ and $\mathbf{2 a}$ in comparison to the PTSC ligand [7]. For the vanadium(V) complex 1a (Fig. 5), the coordination polyhedron around the metal ion is intermediate between square-pyramidal and trigonal-bipyramidal with $\tau=0.37$ ( $\tau=1$ for an ideal trigonal bipyramid, $\tau=0$ for an ideal square pyramid) [34]. The vanadium(V) is coordinated by one tridentate deprotonated PTSC ligand $\left(\mathrm{L}^{-}\right)$via the pyridine nitrogen atom as well as the nitrogen and sulfur donors of the thiosemicarbazide moiety and two oxido ligands with bond length in the expected range for such type of complexes $[21,24]$.

\section{Figure 5, Table 5}

In contrast, in the oxovanadium(IV) complex $\mathbf{2 a}$, the coordination polyhedron approaches an octahedron, where one tridentate PTSC, a bidentate acac, and an oxido ligand is coordinated to the metal center (Fig. 5). Comparably to complex 1a, the ligand is deprotonated $\left(\mathrm{L}^{-}\right)$. Of note is the difference in the bond length from vanadium(IV) to the acac oxygen atoms with $\mathrm{V}-\mathrm{O} 1$ at $1.984 \AA$ and $\mathrm{V}-\mathrm{O} 2$ at $2.155 \AA$. The enlongated bond length of $\mathrm{V}-$ $\mathrm{O} 2$ can be explained by the trans influence of the oxido ligand and is in agreement with a similar structure with 2-acetylpyridine-4-phenylthiosemicarbazone [35]. In crystal structures of both, 1a and 2a, deprotonation of the PTSC ligand is accompanied with a distinct elongation of the C7-S bond (1a: $1.737 \AA \AA$; $2 \mathbf{a}: 1.751 \AA$ ) compared to the metal-free ligand at 
$1.686 \AA$ indicating an increased single-bond character [7]. In addition, the C7-N3 bond decreases from $1.373 \AA$ to $1.325 \AA$ in $\mathbf{1 a}$ and $1.334 \AA$ in $\mathbf{2 a}$, respectively.

\subsection{Cytotoxicity of complexes $\mathbf{1 a}, \mathbf{1 b}$, and $\mathbf{2 a}$}

As a next step, the cytotoxicity of the novel synthesized compounds $\left(\mathrm{IC}_{50}\right.$ values in $\mathrm{nM}$ ) of 1a, 1b, and 2a in comparison to their metal-free ligands were measured in three human cancer cell lines (colon carcinoma SW480, ovarian carcinoma A2780, and epidermal carcinoma-derived KB-3-1 cells). Table 6 shows the $\mathrm{IC}_{50}$ values for the compounds after $72 \mathrm{~h}$ incubation measured by the 3-(4,5-dimethyl-2-thiazolyl)-2,5-diphenyl-2H-tetrazolium bromide (MTT) assay.

\section{Table 6}

In general, A2780 cells were found to be the most sensitive of the investigated cell lines, whereas SW480 and KB-3-1 cells were less affected by the compounds. In accordance to the literature, PTSC had $\mathrm{IC}_{50}$ values in the (low) nanomolar range, whereas, APTSC was active at low $\mu \mathrm{M}$ concentrations comparable to Triapine [7]. Interestingly, the sensitivity profile of SW480 cells was strongly different from KB-3-1 and A2780. These two cell models were very sensitive towards PTSC and its complexes, while in SW480 cells a distinctly reduced activity was observed. In contrast, APTSC and its vanadium complex showed quite similar activity in all three cell lines. This probably originates from differences in the mode of action, which were observed for PTSC compared to APTSC [36]. Despite these differences originating from the ligand properties, the impact of vanadium complexation was rather weak. Thus, only in KB-3-1a non-significant tendency for increased activity of $\mathbf{1 a}$ and $\mathbf{2 a}$ in comparison to the respective free ligand was observed. In contrast, $\mathbf{1 b}$ was slightly less active than APTSC in all tested cell lines. This lack of impact can most probably be explained by the release of the ligands due to the low solution stability of these vanadium complexes already in the low micro- to nanomolar concentration range.

\subsection{Complex formation of STSC with vanadium(IV/V) ions and cytotoxicity studies}

In order to investigate whether the solution stability of vanadium(IV/V) complexes of tridentate thiosemicarbazones and their cytotoxicity can be increased by exchange of the pyridyl nitrogen for a harder Lewis acid donor atom with higher affinity to the vanadium ions, STSC with a phenolate oxygen was chosen as a test compound (Chart 1). 
The acid-base properties of STSC have already been studied in detail in our previous work [25], and the $\mathrm{p} K_{\mathrm{a}}$ values determined here are in good agreement with the published data (Table 1). The $\mathrm{p} K_{1}$ and $\mathrm{p} K_{2}$ values of the ligand can be attributed to deprotonation of the phenolic $\mathrm{OH}$ group as well as the hydrazinic-NH of the thiosemicarbazide moiety. Noteworthy, the proton dissociation constant of the azomethine nitrogen atom ( $\left.\mathrm{p} K_{2}\right)$ of STSC is significantly higher compared to that of the $\alpha(\mathrm{N})$-pyridyl TSCs. This can be explained by the different total charge of the ligands in the mono-protonated form: the $\alpha(\mathrm{N})$-pyridyl TSCs are neutral, while STSC has one negative charge. It was found that STSC is mainly present in the neutral form $\left(96 \% \mathrm{H}_{2} \mathrm{~L} ; 4 \% \mathrm{HL}^{-}\right)$at physiological $\mathrm{pH}$ and its $\log D_{7.4}$ value [25] is considerably higher compared to those of the $\alpha(\mathrm{N})$-pyridyl TSCs (Table 1).

The V(IV)O-binding ability of STSC was studied by pH-potentiometry and EPR methods. The $\mathrm{pH}$-potentiometric data reveal the formation of mono-ligand species: $[\mathrm{V}(\mathrm{IV}) \mathrm{O}(\mathrm{LH})]^{+},[\mathrm{V}(\mathrm{IV}) \mathrm{O}(\mathrm{L})]$ as well as $\left[\mathrm{V}(\mathrm{IV}) \mathrm{O}(\mathrm{L}) \mathrm{H}_{-1}\right]^{-}$comparably to previous data on complexes formed with other bivalent metal ions such as $\mathrm{Cu}(\mathrm{II})$ and $\mathrm{Zn}$ (II) [12]. Overall stability constants of the V(IV)O-STSC complexes are summarized in Table 1. Based on the deconvolution of the EPR spectra recorded at room temperature, a component spectrum (Fig. 6a) and isotropic EPR parameters (Table 2) of the complex [V(IV)O(L)] could be calculated. Notably, data for $[\mathrm{V}(\mathrm{IV}) \mathrm{O}(\mathrm{LH})]^{+}$and $\left[\mathrm{V}(\mathrm{IV}) \mathrm{O}\left(\mathrm{L}_{2} \mathrm{H}_{-1}\right]^{-}\right.$could not be obtained with proper accuracy. This is most probably due to the low molar fraction of the protonated complex and the partial oxidation process in the $\mathrm{pH}$ range of the formation of $\left[\mathrm{V}(\mathrm{IV}) \mathrm{O}(\mathrm{L}) \mathrm{H}_{-1}\right]^{-}$. Notably, the $g_{0}$ value of $[\mathrm{V}(\mathrm{IV}) \mathrm{O}(\mathrm{L})]$ is slightly higher, although $A_{0}$ is in the same range, compared to the parameters of the corresponding complexes of Triapine, APTSC, and PTSC. It is noteworthy that the oxovanadium(IV) complex of salicylaldehyde semicarbazone (SSC) with $\left(\mathrm{O}^{-}, \mathrm{N}, \mathrm{O}^{-}\right)$binding mode possesses significantly different EPR parameters $\left(g_{0}=1.9674, A_{0}=\right.$ 101.4 G $/ 93.1 \times 10^{-4} \mathrm{~cm}^{-1}$ ) [37]. The most feasible binding mode in the [V(IV)O(L)] complex of STSC is a coordination via the $\left(\mathrm{O}^{-}, \mathrm{N}, \mathrm{S}^{-}\right)$donor set together with a deprotonated hydrazine moiety. This is in agreement with some X-ray crystal structures for ternary oxovanadium(IV) complexes of STSC or its derivatives formed with $(\mathrm{N}, \mathrm{N})$ bidentate aromatic co-ligands such as 1,10-phenanthroline or 2,2'-bipyridine in literature [23,38]. In the protonated $[\mathrm{V}(\mathrm{IV}) \mathrm{O}(\mathrm{LH})]^{+}$species the ligand most likely coordinates via $\left(\mathrm{O}^{-}, \mathrm{N}, \mathrm{S}\right)$ donor atoms (with protonated $\mathrm{NH}$ group), while $\left[\mathrm{V}(\mathrm{IV}) \mathrm{O}(\mathrm{L}) \mathrm{H}_{-1}\right]^{-}$is a mixed hydroxido complex (= $\left.[\mathrm{V}(\mathrm{IV}) \mathrm{O}(\mathrm{L})(\mathrm{OH})]^{-}\right)$.

Due to the higher ligand basicity (higher $\mathrm{p} K_{\mathrm{a}}$ values) of STSC compared to the $\alpha(\mathrm{N})$ pyridyl TSCs, stronger ligand effectiveness is expected at higher $\mathrm{pH}$ values. Indeed, the 
increased oxovanadium(IV) binding ability of STSC over the $\alpha(\mathrm{N})$-pyridyl TSCs is clearly reflected in the conditional stability constants (see $\log K^{\prime}$ values calculated at $\mathrm{pH} 7.4$ in Table 1) and the higher fractions of the bound metal ion in a broader $\mathrm{pH}$ range including $\mathrm{pH} 7.4$ (c.f. Figs. $6 \mathrm{~b}$ and 1). Thus, the involvement of the phenolate oxygen into the coordination instead of the pyridyl nitrogen results in more favorable complex formation with $\mathrm{V}(\mathrm{IV}) \mathrm{O}$.

\section{Figure 6}

Since no redox reaction was observed, the V(V) - STSC system could be monitored over a wider $\mathrm{pH}$ range by ${ }^{51} \mathrm{~V}$ NMR spectroscopy (Fig. 7.a/b) compared to the $\alpha(\mathrm{N})$-pyridyl TSCs. The recorded spectra represented formation of isomeric species (1) and (2) and three groups of signals were identified as follows: i) unbound $\mathrm{V}(\mathrm{V})$ as $\mathrm{HV}(\mathrm{V}) \mathrm{O}_{4}{ }^{2-}$ and $\mathrm{H}_{2} \mathrm{~V}(\mathrm{~V}) \mathrm{O}_{4}{ }^{-}$; ii) bound $\mathrm{V}(\mathrm{V})$ as $\left[\mathrm{V}(\mathrm{V}) \mathrm{O}_{2}(\mathrm{LH})\right](1)$ and $\left[\mathrm{V}(\mathrm{V}) \mathrm{O}_{2}(\mathrm{~L})\right]^{-}(1)$ as well as iii) $\left[\mathrm{V}(\mathrm{V}) \mathrm{O}_{2}(\mathrm{~L})\right]^{-}$(2) and $\left[\mathrm{V}(\mathrm{V}) \mathrm{O}_{2}(\mathrm{~L}) \mathrm{H}_{-1}\right]^{2-}$ (2) (Fig. 7.b). Based on the $\mathrm{pH}$-dependence of the chemical shifts of the peaks, equilibrium constants were calculated for protonation of the $\mathrm{HV}(\mathrm{V}) \mathrm{O}_{4}{ }^{2-},\left[\mathrm{V}(\mathrm{V})_{2}(\mathrm{~L})\right]^{-}$ (1) and $\left[\mathrm{V}(\mathrm{V}) \mathrm{O}_{2}(\mathrm{~L}) \mathrm{H}_{1}\right]^{2-}$ (2) species (Table 4). For the major isomer $\left[\mathrm{V}(\mathrm{V}) \mathrm{O}_{2}(\mathrm{~L})\right]^{-}$(1) formed between $\mathrm{pH} \sim 3$ and $\sim 11$, our data suggest ligand coordination most probably via the $\left(\mathrm{O}^{-}, \mathrm{N}^{2}, \mathrm{~S}^{-}\right)$donor set together with protonation of the $\mathrm{N}^{3}$ thiosemicarbazone nitrogen. This results in formation of $\left[\mathrm{V}(\mathrm{V}) \mathrm{O}_{2}(\mathrm{LH})\right]$ (1) with an $\left(\mathrm{O}^{-}, \mathrm{N}^{2}, \mathrm{~S}\right)$-binding mode, which is in agreement with literature reports on solid phase structures for $\left[\mathrm{V}(\mathrm{V}) \mathrm{O}_{2}(\mathrm{~L})\right]^{-}$and $\left[\mathrm{V}(\mathrm{V}) \mathrm{O}_{2}(\mathrm{LH})\right]$ of STSC representing these coordination modes [22]. Based on the integrated areas the ratio of major and minor isomers of $\left[\mathrm{V}(\mathrm{V}) \mathrm{O}_{2}(\mathrm{~L})\right]^{-}$is $6.4: 1$ and were detected at -449 ppm and $-577 \mathrm{ppm}$, respectively. This significant difference between the two chemical shifts suggests that besides the tridentate $\left(\mathrm{O}^{-}, \mathrm{N}^{2}, \mathrm{~S}^{-}\right)$-binding mode also a rather different coordination mode exists. In the case of the analogous semicarbazone, SSC, a minor isomer was also found at a similar chemical shift (-575.5 ppm) [37]. In this minor species, the chalcogen atom seems to be non-coordinated and a $\left(\mathrm{O}^{-}, \mathrm{N}^{2}, \mathrm{~N}^{4}\right)$-binding mode is feasible. Notably, the $\left[\mathrm{V}(\mathrm{V}) \mathrm{O}_{2}(\mathrm{~L})\right]^{-}$(2) isomer has no protonated form but is able to form a mixed hydroxide species $\left[\mathrm{V}(\mathrm{V}) \mathrm{O}_{2}(\mathrm{~L}) \mathrm{H}_{-1}\right]^{2-}(2)$ in the basic $\mathrm{pH}$ range.

\section{Figure 7}

Representative concentration distributions curves are shown for the V(V) - STSC system in Fig. 8 calculated with the aid of the determined stability data (Table 4). It could be concluded that the species $\left[\mathrm{V}(\mathrm{V}) \mathrm{O}_{2}(\mathrm{~L})\right]^{-}(1)$ and (2) are predominant at neutral $\mathrm{pH}$.

Figure 8

In order to compare the vanadium(IV/V) binding ability of the studied TSC ligands $\mathrm{pM}^{*}$ values were also calculated at $\mathrm{pH} 7.4$ (Table $\mathrm{S} 2$ ). $\mathrm{pM}^{*}$ is the negative logarithm of the 
summed equilibrium concentration of the non-bound metal ion and its hydroxido species under the conditions employed. According to these values the ligand effectiveness is for both the $\mathrm{V}(\mathrm{IV}) \mathrm{O}$ and $\mathrm{V}(\mathrm{V})$ ions in the following order: Triapine $<$ APTSC, PTSC $<<$ STSC. Thus, the solution equilibrium studies clearly revealed that the exchange of the $\alpha$-pyridyl nitrogen by a phenolate oxygen indeed resulted in formation of complexes with distinctly higher stability. To investigate if this is also reflected in the biological activity, a cytotoxicity test of the system with highest stability (V(V) with STSC) was performed in analogy to the biological investigations of the $\alpha$-pyridyl TSCs above. In these experiments, metal-free STSC showed hardly any activity with $\mathrm{IC}_{50}$ value of $>100 \mu \mathrm{M}$ in all three cell lines (KB-3-1, SW480 and A2780 cells). In contrast, co-incubation of STSC with $\mathrm{NaVO}_{3}$ in 1:1 ratio at $\mathrm{pH}$ 7.4 (with formation of $\left[\mathrm{V}(\mathrm{V}) \mathrm{O}_{2}(\mathrm{~L})\right]^{-}$) was found to increase the cytotoxicity especially in A2780 cells to an $\mathrm{IC}_{50}$ of $27.4 \pm 8.2 \mu \mathrm{M}$ (in the other two cell lines the $\mathrm{IC}_{50}$ value was still > $100 \mu \mathrm{M})$. In general, it is well known that STSC possesses significantly lower antiproliferative activity [39] compared to the class of $\alpha(\mathrm{N})$-pyridyl TSCs [7]. This can probably be explained by the fact that $\alpha(\mathrm{N})$-pyridyl TSCs were found to be unambiguously more efficient chelators for $\mathrm{Fe}(\mathrm{II})$ than STSC over a wide $\mathrm{pH}$ range [25]. This indicates that in case of STSC the redox cycling of the intracellularly formed iron complexes, which is assumed to be crucial for the activity of thiosemicarbazones, is hampered [6].

\section{Conclusions}

In the here presented study, stoichiometry and stability of vanadium(IV/V) complexes formed with Triapine and two derivatives with dimethylated terminal amino groups (APTSC and PTSC) were studied in $30 \%(\mathrm{w} / \mathrm{w}) \mathrm{DMSO} / \mathrm{H}_{2} \mathrm{O}$ solvent mixture focusing on the most plausible species emerging at physiological pH. Stability constants and the most feasible coordination modes were determined by pH-potentiometry and EPR in the case of the oxovanadium(IV) complexes, while ${ }^{51} \mathrm{~V}$ NMR spectroscopy was applied as the main tool for studying the complexation of vanadium(V). Formation of only mono-ligand oxovanadium(IV) complexes such as $[\mathrm{V}(\mathrm{IV}) \mathrm{O}(\mathrm{L})]^{+}$and $[\mathrm{V}(\mathrm{IV}) \mathrm{O}(\mathrm{L})(\mathrm{OH})]$ was found with Triapine, APTSC, and PTSC. Here, coordination of ligand most probable occurs in a tridentate mode via an $\left(\mathrm{N}_{\mathrm{pyr}}, \mathrm{N}, \mathrm{S}^{-}\right)$donor set, while the hydrazinic- $\mathrm{N}$ is deprotonated. Triapine was found to be an inefficient oxovanadium(IV) binder at neutral $\mathrm{pH}$, whereas the terminally dimethylation results in an enhancement of the complex stability. This is also true for $V(V)$ : 
Triapine was not able to bind V(V) at $\mathrm{pH} 7.4$, whereas APTSC and PTSC form [V(V)O $\left.\mathrm{O}_{2}(\mathrm{~L})\right]$ type complexes, which possessed even somewhat higher stabilities than the oxovanadium(IV) species.

Subsequently, vanadium complexes of PTSC and APTSC with adequate stability at physiological $\mathrm{pH}$ were synthesized and in detail characterized followed by cell culture tests in human cancer cell lines. Overall, the vanadium complexes exhibited widely identical anticancer activity as compared to the corresponding ligands implying that the vanadium binding in these complexes is not sufficient to impact on the biological activity.

In order to increase the solution stability of vanadium(IV/V)-TSC complexes, as a next step, STSC, a ligand containing a phenolate oxygen donor atom instead of the pyridyl nitrogen was investigated in our studies. The results showed that STSC forms complexes with oxovanadium(IV) characterized by an $\left(\mathrm{O}^{-}, \mathrm{N}^{2}, \mathrm{~S}\right)$-binding mode and a protonated hydrazinic $\mathrm{NH}$ moiety $\left([\mathrm{V}(\mathrm{IV}) \mathrm{O}(\mathrm{LH})]^{+}\right)$. In addition, species with a completely deprotonated ligand coordinated through an $\left(\mathrm{O}^{-}, \mathrm{N}^{2}, \mathrm{~S}^{-}\right)$donor set $\left([\mathrm{V}(\mathrm{IV}) \mathrm{O}(\mathrm{L})]\right.$ and $\left.[\mathrm{V}(\mathrm{IV}) \mathrm{O}(\mathrm{L})(\mathrm{OH})]^{-}\right)$were observed (with V(V) similar species were detected). The stabilities of the vanadium(IV/V) complexes of STSC were found to be significantly higher than that of the $\alpha(\mathrm{N})$-pyridyl TSCs. Cytotoxicity measurements of a STSC-V(V) complex revealed an increase of the anticancer activity compared to the very low activity of the metal-free STSC ligand. In general, the cytotoxic activity of STSC was strongly decreased compared to $\alpha(\mathrm{N})$-pyridyl TSCs. Thus STSC derivatives with higher anticancer activity e.g. terminal dimethylated derivatives will be investigated in subsequent studies to further increase the stability and shift the biological activity to the low micromolar range.

\section{Experimental}

\subsection{Chemicals}

Triapine, PTSC, and APTSC were prepared as described previously [7,31]. STSC was purchased from Sigma-Aldrich and used without further purification. The exact concentration of the ligand stock solutions together with the proton dissociation constants were determined by $\mathrm{pH}$-potentiometric titrations with aid of the computer program HYPERQUAD [40]. $\mathrm{NaVO}_{3}, \mathrm{VOSO}_{4}, \mathrm{KOH}, \mathrm{D}_{2} \mathrm{O}$, and DMSO- $d_{6}$ were purchased from Sigma-Aldrich and $\mathrm{HCl}$, $\mathrm{KCl}$ was well as DMSO from Reanal. The V(IV)O stock solution was prepared as described 
[41] and standardized for the metal ion concentration by permanganate titration. Vanadate stock solution was prepared by dissolving $\mathrm{NaVO}_{3}$ in $\mathrm{KOH}$ solution and its concentration was calculated based on mass and total volume. Double distilled Milli-Q water was used for sample preparations.

All solvents used for synthesis were of analytical grade and used without further purification. $\mathrm{V}_{2} \mathrm{O}_{4}(\mathrm{acac})_{2}$ was synthesized according to literature procedures [32]. Elemental analyses were carried out on a Carlo Erba microanalyzer at the Microanalytical Laboratory of the University of Vienna. Electrospray ionization mass spectrometry (ESI-MS) was carried out with a Bruker Esquire 3000 instrument (Bruker Daltonic, Bremen, Germany). Expected and experimental isotope distributions were compared. UV-vis spectra for the complexes were recorded on a Perkin Elmer Lambda 650 UV-vis spectrophotometer using samples dissolved in methanol $(900-210 \mathrm{~nm}) .{ }^{1} \mathrm{H}$ and ${ }^{13} \mathrm{C}$ one- and two-dimensional NMR spectra were recorded in DMSO- $d_{6}$, with a Bruker Avance III 500 MHz FT-NMR spectrometer. The residual ${ }^{1} \mathrm{H}$ and ${ }^{13} \mathrm{C}$ present in DMSO- $d_{6}$ were used as internal references. ${ }^{51} \mathrm{~V}$ NMR spectra for the complexes were recorded in DMSO- $d_{6}$ with a Bruker Avance DRX $500 \mathrm{MHz}$ spectrometer. (Abbreviations for NMR data: py $=$ pyridine, $\mathrm{C}_{\mathrm{q}}$, py $=$ quaternary carbon of pyridine.)

\subsection{Synthesis of vanadium(IV/V) complexes of PTSC and APTSC}

(2-Formylpyridine

N,N-dimethylthiosemicarbazonato)dioxovanadium(V), $\left[\mathrm{V}(\mathrm{V}) \mathrm{O}_{2}(\mathrm{~L})\right]$ complex of PTSC (1a): PTSC (115 mg, $\left.0.55 \mathrm{mmol}\right)$ was dissolved in hot methanol $(5 \mathrm{~mL})$, added to $\mathrm{V}_{2} \mathrm{O}_{4}(\mathrm{acac})_{2}(100 \mathrm{mg}, 0.27 \mathrm{mmol})$ in methanol $(5 \mathrm{~mL})$ and the mixture was stirred for $3 \mathrm{~min}$. The orange precipitate formed was filtered off, washed with cold methanol $\left(-20{ }^{\circ} \mathrm{C}\right)$ and dried in vacuo. Yield: $118 \mathrm{mg}(74 \%)$. Anal. Calcd. for $\mathrm{C}_{9} \mathrm{H}_{11} \mathrm{~N}_{4} \mathrm{O}_{2} \mathrm{SV}\left(M_{\mathrm{r}}=290.22 \mathrm{~g} / \mathrm{mol}\right): \mathrm{C}, 37.25 ; \mathrm{H}, 3.82 ; \mathrm{N}, 19.31 ; \mathrm{S}, 11.05$. Found: C, 37.15; $\mathrm{H}, 3.68$; N, 19.11; S, 11.20. ESI-MS in methanol (positive): $m / z 313,[\mathrm{M}+\mathrm{Na}]^{+} ; 329,[\mathrm{M}+\mathrm{K}]^{+}$. UV-vis (methanol), $\lambda_{\max }, \mathrm{nm}\left(\varepsilon, \mathrm{M}^{-1} \mathrm{~cm}^{-1}\right): 221$ (10015), 281 (5615), 490 (6940). ${ }^{1} \mathrm{H}$ NMR $\left(500.10 \mathrm{MHz}, \mathrm{DMSO}-d_{6}\right): \delta 8.58\left(\mathrm{~d}, 1 \mathrm{H}, \mathrm{py},{ }^{3} J_{\mathrm{H}, \mathrm{H}}=4 \mathrm{~Hz}\right), 8.54(\mathrm{~s}, 1 \mathrm{H}, \mathrm{HC}=\mathrm{N}), 8.24(\mathrm{~m}, 1 \mathrm{H}$, py), $7.87\left(\mathrm{~d}, 1 \mathrm{H}, \mathrm{py},{ }^{3} \mathrm{~J}_{\mathrm{H}, \mathrm{H}}=8 \mathrm{~Hz}\right), 7.57(\mathrm{~m}, 1 \mathrm{H}, \mathrm{py}), 3.27\left(\mathrm{~s}, 6 \mathrm{H}, \mathrm{N}\left(\mathrm{CH}_{3}\right)_{2}\right) .{ }^{13} \mathrm{C} \mathrm{NMR}(125.81$ MHz, DMSO-d $\left.)_{6}\right): \delta 178.2(\mathrm{C}-\mathrm{S}), 154.2\left(\mathrm{C}_{\mathrm{q}}, \mathrm{py}\right), 153.6\left(\mathrm{C}_{\mathrm{py}}\right), 146.7(\mathrm{HC}=\mathrm{N}), 143.5\left(\mathrm{C}_{\mathrm{py}}\right)$, $125.7\left(\mathrm{C}_{\mathrm{py}}\right), 125.4\left(\mathrm{C}_{\mathrm{py}}\right), 40.3\left(\mathrm{~N}_{\left.\left(\mathrm{CH}_{3}\right)_{2}\right) .}{ }^{51} \mathrm{~V} \mathrm{NMR}\left(500 \mathrm{MHz}, \mathrm{DMSO}-d_{6}\right)\right.$ : -427.5 ppm. After a few days crystals suitable for X-ray data collection were directly obtained from the mother liquor. 

$\left[\mathrm{V}(\mathrm{V}) \mathrm{O}_{2}(\mathrm{~L})\right]$ complex of APTSC (1b): APTSC (90 mg, $\left.0.40 \mathrm{mmol}\right)$ was suspended in methanol $(4 \mathrm{~mL})$, added to $\mathrm{V}_{2} \mathrm{O}_{4}(\mathrm{acac})_{2}(73 \mathrm{mg}, 0.20 \mathrm{mmol})$ in methanol $(4 \mathrm{~mL})$ and the mixture was stirred for $1.5 \mathrm{~h}$ at room temperature. The dark-red precipitate formed was filtered off, washed with methanol and dried in vacuo. Yield: $77 \mathrm{mg}(63 \%)$. Anal. Calcd. for $\mathrm{C}_{9} \mathrm{H}_{12} \mathrm{~N}_{5} \mathrm{O}_{2} \mathrm{SV}\left(M_{\mathrm{r}}=305.23 \mathrm{~g} / \mathrm{mol}\right): \mathrm{C}, 35.41 ; \mathrm{H}, 3.96$; N, 22.94; S, 11.05. Found: C, 35.54; $\mathrm{H}, 3.80 ; \mathrm{N}, 22.63 ; \mathrm{S}, 10.59$. ESI-MS in methanol (positive mode): $\mathrm{m} / z \mathrm{329},[\mathrm{M}+\mathrm{Na}]^{+} ; 344$, $[\mathrm{M}+\mathrm{K}]^{+} . \mathrm{UV}$-vis (methanol), $\lambda_{\max }, \mathrm{nm}\left(\varepsilon, \mathrm{M}^{-1} \mathrm{~cm}^{-1}\right): 257$ (3030), 280 (2890), 299sh (2740), 445 (3560). ${ }^{1} \mathrm{H}$ NMR (500.10 MHz, DMSO-d $)$ ): $\delta 8.89(\mathrm{~s}, 1 \mathrm{H}, \mathrm{HC}=\mathrm{N}), 7.83\left(\mathrm{~d}, 1 \mathrm{H}, \mathrm{py},{ }^{3} J_{\mathrm{H}, \mathrm{H}}\right.$ $=5 \mathrm{~Hz}), 7.36\left(\mathrm{dd}, 1 \mathrm{H}, \mathrm{py},{ }^{3} J_{\mathrm{H}, \mathrm{H}}=9 \mathrm{~Hz},{ }^{4} J_{\mathrm{H}, \mathrm{H}}=1 \mathrm{~Hz}\right), 7.26\left(\mathrm{dd}, 1 \mathrm{H}, \mathrm{py},{ }^{3} J_{\mathrm{H}, \mathrm{H}}=9 \mathrm{~Hz},{ }^{3} J_{\mathrm{H}, \mathrm{H}}=5\right.$ $\mathrm{Hz}), 6.64\left(\mathrm{~s}, 2 \mathrm{H}, \mathrm{NH}_{2}\right), 3.22\left(\mathrm{~s}, 6 \mathrm{H}, \mathrm{N}\left(\mathrm{CH}_{3}\right)_{2}\right) .{ }^{13} \mathrm{C} \mathrm{NMR}\left(125.81 \mathrm{MHz}, \mathrm{DMSO}-d_{6}\right): \delta 176.2$ $(\mathrm{C}-\mathrm{S}), 146.2(\mathrm{HC}=\mathrm{N}), 145.7\left(\mathrm{C}_{\mathrm{q}}, \mathrm{py}\right), 142.5\left(\mathrm{C}_{\mathrm{py}}\right), 135.5\left(\mathrm{C}_{\mathrm{q}}, \mathrm{py}\right), 128.5\left(\mathrm{C}_{\mathrm{py}}\right), 126.9\left(\mathrm{C}_{\mathrm{py}}\right), 40.3$ $\left(\mathrm{N}\left(\mathrm{CH}_{3}\right)_{2}\right) \cdot{ }^{51} \mathrm{~V}$ NMR $\left(500 \mathrm{MHz}, \mathrm{DMSO}-d_{6}\right):-430.0 \mathrm{ppm}$.

(Acetylacetonato(2-formylpyridine N,N-dimethylthiosemicarbazonato)oxovanadium(IV), [V(IV)O(L)(acac)] complex of PTSC (2a): Under an argon atmosphere, PTSC (79 mg, 0.38 mmol) was added as a solid to a solution of $\mathrm{VO}(\mathrm{acac})_{2}(100 \mathrm{mg}, 0.38 \mathrm{mmol})$ in ethanol (10 $\mathrm{mL}$ ) and the mixture was stirred for $1.5 \mathrm{~h}$. The green precipitate formed was filtered off, washed with isopropanol, and dried in vacuo. Yield: $110 \mathrm{mg}$ (78\%). Anal. Calcd. for $\mathrm{C}_{14} \mathrm{H}_{18} \mathrm{~N}_{4} \mathrm{O}_{3} \mathrm{SV}\left(M_{\mathrm{r}}=373.32 \mathrm{~g} / \mathrm{mol}\right): \mathrm{C}, 45.04 ; \mathrm{H}, 4.86 ; \mathrm{N}, 15.01 ; \mathrm{S}, 8.59$. Found: $\mathrm{C}, 44.86 ; \mathrm{H}$, 4.98; N, 14.72; S, 8.63. ESI-MS in methanol (positive mode): $m / z 396,[\mathrm{M}+\mathrm{Na}]^{+} ; 412$, $[\mathrm{M}+\mathrm{K}]^{+} . \mathrm{UV}-\mathrm{vis}$ (methanol), $\lambda_{\max }, \mathrm{nm}\left(\varepsilon, \mathrm{M}^{-1} \mathrm{~cm}^{-1}\right): 268$ (10740), 347sh (3955), 433 (5930). Crystals suitable for X-ray data collection were obtained by slow diffusion of ether into a solution of $\mathbf{2 a}$ in dichloromethane under an argon atmosphere.

\subsection{Crystallographic structure determination of $1 \mathbf{a}$ and $\mathbf{2 a}$}

X-ray diffraction measurements were performed on a Bruker X8 APPEXII CCD diffractometer. A single crystal of suitable size was coated with Paratone-N oil, mounted at room temperature on a cryo loop and cooled under a stream of cold $\mathrm{N}_{2}$ maintained by a KRYOFLEX low-temperature apparatus. Crystals of 1a and 2a were positioned at $35 \mathrm{~mm}$ from the detector, and 1820/835 frames were measured, each for $30 / 60 \mathrm{~s}$ over $1^{\circ} \mathrm{scan}$ width. The data were processed using SAINT software [42]. The structures were solved by direct 
methods and refined by full-matrix least-squares techniques. Non-hydrogen atoms were refined with anisotropic displacement parameters. $\mathrm{H}$ atoms were placed at calculated positions and refined as riding atoms in the subsequent least squares model refinements. The following software programs and computer were used: structure solution, SHELXS-97 [43]; refinement, SHELXL-97 [43]; molecular diagrams, ORTEP [44]; computer: Intel CoreDuo. Crystal data and structure refinement details for 1a and 2a are given in Table S1. Crystallographic data have been deposited at the Cambridge Crystallographic Data Center with numbers CCDC1021658 and 1021659.

\section{4. pH-potentiometric measurements}

The $\mathrm{pH}$-metric measurements for determination of the protonation constants of the ligands and the overall stability constants of the V(IV)O complexes were carried out at $25.0 \pm$ $0.1{ }^{\circ} \mathrm{C}$ in DMSO:water 30:70 (w/w) as solvent and at an ionic strength of $0.10 \mathrm{M}(\mathrm{KCl})$ in order to keep the activity coefficients constant. The titrations were performed with carbonatefree $\mathrm{KOH}$ solution of known concentration $(0.10 \mathrm{M})$. The concentrations of the base and the $\mathrm{HCl}$ were determined by $\mathrm{pH}$-potentiometric titrations. An Orion 710A pH-meter equipped with a Metrohm combined electrode (type 6.0234.100) and a Metrohm 665 Dosimat burette were used for the $\mathrm{pH}$-metric measurements. The electrode system was calibrated to the $\mathrm{pH}=$ $-\log \left[\mathrm{H}^{+}\right]$scale in the DMSO/water solvent mixture by means of blank titrations (strong acid vs. strong base; $\mathrm{HCl} v s . \mathrm{KOH})$, similarly to the method suggested by Irving et al. [45] in pure aqueous solutions. The average water ionization constant, $\mathrm{p} K_{\mathrm{w}}$, is $14.52 \pm 0.05$ in DMSO:water 30:70 (w/w) at $25{ }^{\circ} \mathrm{C}$, which corresponds well to the literature $[8,9,46]$ and results in $\mathrm{pH} 7.26$ as neutral $\mathrm{pH}$. The reproducibility of the titration points included in the calculations was within $0.005 \mathrm{pH}$. The $\mathrm{pH}$-metric titrations were performed in the $\mathrm{pH}$ range 2.0-12.6. The initial volume of the samples was $10.0 \mathrm{~mL}$. The ligand concentration was 1 or 2 $\mathrm{mM}$ and metal ion to ligand ratios of 1:1-1:5 were used. The accepted fitting of the titration curves was always less than $0.01 \mathrm{~mL}$. Samples were deoxygenated by bubbling purified argon through them for $c a$. 10 min prior to the measurements. In the case of $\mathrm{V}^{\mathrm{IV}} \mathrm{O}$-containing samples, argon overpressure was used when metal ion solution was added to the samples in tightly closed vessels, which were prior completely deoxygenated by bubbling a stream of purified argon through them for $c a$. $20 \mathrm{~min}$. Argon was also passed over the solutions during the titrations. 
The protonation constants of the ligands were determined with the computer program HYPERQUAD [40], and PSEQUAD [47] was utilized to establish the stoichiometry of the complexes and to calculate the stability constants $\left(\log \beta\left(\mathrm{M}_{p} \mathrm{~L}_{q} \mathrm{H}_{r}\right)\right)$ using the literature data for $\mathrm{V}(\mathrm{IV}) \mathrm{O}$ hydroxido complexes [48]. It is noteworthy that hydrolysis constants of $\mathrm{V}(\mathrm{IV}) \mathrm{O}$ hydroxido complexes are not known in the literature for the applied solvent mixture. $\left(\mathrm{M}_{p} \mathrm{~L}_{q} \mathrm{H}_{r}\right)$ is defined for the general equilibrium $p \mathrm{M}+q \mathrm{~L}+r \mathrm{H} \rightleftharpoons \mathrm{M}_{p} \mathrm{~L}_{q} \mathrm{H}_{r}$ as $\beta\left(\mathrm{M}_{p} \mathrm{~L}_{q} \mathrm{H}_{r}\right)=$ $\left[\mathrm{M}_{p} \mathrm{~L}_{q} \mathrm{H}_{r}\right] /[\mathrm{M}]^{p}[\mathrm{~L}]^{q}[\mathrm{H}]^{r}$, where $\mathrm{M}$ denotes the metal ion (V(IV)O) and $\mathrm{L}$ the completely deprotonated ligands. In all calculations, exclusively titration data were used from experiments in which no precipitate was visible in the reaction mixture.

\subsection{UV-vis spectrophotometric and ${ }^{51} V$ NMR measurements}

A Hewlett Packard 8452A diode array spectrophotometer was used to record the UVvis spectra in the interval $260-820 \mathrm{~nm}$. The path length was $1 \mathrm{~cm}$. Protonation and stability constants and the individual spectra of the species were calculated by the computer program PSEQUAD [47]. The spectrophotometric titrations were performed on samples of the pure TSCs or with $\mathrm{V}(\mathrm{IV}) \mathrm{O}$; the concentration of ligand was 50 or $63 \mu \mathrm{M}$ and the metal-to-ligand ratios were 1:1 and 1:2 over the $\mathrm{pH}$ range between 2 and 12.6 at an ionic strength of $0.10 \mathrm{M}$ $\mathrm{KCl}$ in $30 \%(\mathrm{w} / \mathrm{w}) \mathrm{DMSO} / \mathrm{H}_{2} \mathrm{O}$ at $25.0 \pm 0.1{ }^{\circ} \mathrm{C}$. For V(IV)O samples, spectra were recorded under anaerobic conditions.

${ }^{51} \mathrm{~V}$ NMR studies were carried out on a Bruker Avance DRX500 instrument and a spectral window of $760 \mathrm{ppm}$, a $90^{\circ}$ pulse angle and an acquisition time of $0.65 \mathrm{~s}$ with a relaxation delay of $0.5 \mathrm{~s}$ and a pulse width of $7 \mathrm{~ms}$ were used. $\mathrm{V}(\mathrm{V}) \mathrm{OCl}_{3}$ was used as an external reference. The TSCs were dissolved in 30\% (v/v) DMSO $60 \% \mathrm{H}_{2} \mathrm{O}$ and $10 \% \mathrm{D}_{2} \mathrm{O}$ at $25{ }^{\circ} \mathrm{C}$ in a concentration of 1.0 or $1.8 \mathrm{mM}$ and the $\mathrm{V}(\mathrm{V}) \mathrm{O}_{2}$-to-ligand ratios were $1: 1$ or 1:1.1. Samples contained $0.10 \mathrm{M} \mathrm{KCl}$. Overall stability or stepwise constants for the complex formation equilibria were determined with the aid of the computer program PSEQUAD [47] on the basis of the integral values and chemical shifts using the literature data for the vanadates $\left(\mathrm{H}^{+} / \mathrm{V}(\mathrm{V})\right)[49]$.

\subsection{Determination of the distribution coefficient (D)}


$D_{7.4}$ values of PTSC and APTSC were determined by the traditional shake flask method in $n$-octanol/buffered aqueous solution at 7.40 (HEPES, $0.01 \mathrm{M}$ ) at $25.0 \pm 0.2{ }^{\circ} \mathrm{C}$. Measurements and calculations were performed similarly as we described previously for Triapine and STSC [25].

\subsection{EPR measurements and deconvolution of the spectra}

All continuous-wave (CW) EPR spectra were recorded with a BRUKER EleXsys E500 spectrometer (microwave frequency $9.81 \mathrm{GHz}$, microwave power $10 \mathrm{~mW}$, modulation amplitude $5 \mathrm{G}$, modulation frequency $100 \mathrm{kHz}$ ). EPR spectra were recorded at $1.0 \mathrm{mM}$ of $\mathrm{V}(\mathrm{IV}) \mathrm{O}$ and the metal-to-ligand ratios were 1:1, 1:2, 1:2 and 1:4 for STSC, APTSC, PTSC, and Triapine, respectively, between $\mathrm{pH} \sim 2-8$ in $30 \%(\mathrm{w} / \mathrm{w}) \mathrm{DMSO} / \mathrm{H}_{2} \mathrm{O}$ mixture at an ionic strength of $0.10 \mathrm{M} \mathrm{KCl}$. For the V(IV)O - Triapine, APTSC, PTSC and STSC systems 4, 4, 8 and 5 isotropic EPR spectra were recorded at room temperature. At higher $\mathrm{pH}$ the EPR signal disappeared possibly because of $\mathrm{V}(\mathrm{IV}) \mathrm{O}$ oxidation, although titrations were carried out under argon atmosphere. Oxidation could be excluded more efficiently in the case of PTSC and spectra of individual samples could be recorded up to $\mathrm{pH} 9.8$.

At certain $\mathrm{pH}$ values, $0.10 \mathrm{~mL}$ of samples were taken out of the solutions into quartz EPR tubes and were measured individually in a Dewar containing liquid nitrogen (at $77 \mathrm{~K}$ ). $\mathrm{KOH}$ solution was added to the stock solution to change the $\mathrm{pH}$ which was measured with an Orion 710A pH-meter equipped with a Metrohm combined electrode (type 6.0234.100).

Series of V(IV)O CW-EPR spectra recorded at $25{ }^{\circ} \mathrm{C}$ were simulated by the ,twodimensional" method using the 2D_EPR program [50]. The $g_{o}$, and $A_{o}{ }^{\mathrm{V}}(I=7 / 2)$ oxovanadium(IV) hyperfine coupling parameters were taken into account to describe each component curve. The relaxation parameters, $\alpha, \beta$, and $\gamma$, defined the line widths through the equation $\sigma_{\mathrm{MI}}=\alpha+\beta \mathrm{M}_{\mathrm{I}}+\gamma \mathrm{M}_{\mathrm{I}}^{2}$, where $\mathrm{M}_{\mathrm{I}}$ denotes the magnetic quantum number of the paramagnetic metal ions.

The anisotropic EPR spectra recorded at $77 \mathrm{~K}$ were analyzed individually with the EPR program [51]. For the V(IV)O complexes $g_{\|}, g \perp$ axial $g$-tensor and $A_{\|}^{\mathrm{V}}, A_{\perp}^{\mathrm{V}}$ axial hyperfine tensor were taken into consideration. The following expressions are valid for the $g$ values in the case of a $\mathrm{d}_{x y}$ ground state and an axial symmetry:

$$
g_{\mathrm{II}}=g_{e}-\frac{8 \alpha^{2} \beta^{2} \xi}{\Delta E\left(x^{2}-y^{2}\right)} \text { and } g_{\perp}=g_{e}-\frac{2 \beta^{2} \gamma^{2} \xi}{\Delta E(x z, y \dot{z})}
$$


Here, $\alpha, \beta$, and $\gamma$ are the vanadium $\underline{\mathrm{d}}_{\underline{x}} \underset{\underline{-}}{2} \underline{\underline{2}}, \mathrm{~d}_{x y}$, and $\mathrm{d}_{x z, y z}$ orbital populations, $\xi$ is the spin-orbit constant, $\Delta E\left(x^{2}-y^{2}\right)$ and $\Delta E(x z, y z)$ are the energy differences between the $\underline{\mathrm{d}}_{\underline{x}}^{2} \underline{\underline{2}} \underline{\underline{2}}, \mathrm{~d}_{x z, y z}$ excited states, respectively, and the $\mathrm{d}_{x y}$ ground state.

For each spectrum, the noise-corrected regression parameter $\left(R_{j}\right.$ for the $j^{\text {th }}$ spectrum) was derived from the average square deviation (SQD) between experimental and calculated intensities. For the series of spectra, the fit is characterized by the overall regression coefficient $R$, calculated from the overall average SQD. The details of the statistical analysis were published previously [51]. The hyperfine and superhyperfine coupling constants and the relaxation parameters were obtained in field units (Gauss $\left.=10^{-4} \mathrm{~T}\right)$ and were calculated to $10^{-4}$ $\mathrm{cm}^{-1}$ by the correspondence of $A\left[10^{-4} \mathrm{~cm}^{-1}\right] \Leftrightarrow 0.4668643 \mathrm{~g} A[\mathrm{G}]$.

\subsection{Cell lines and culture conditions}

The following human cell lines were used in this study: the colon carcinoma cell line SW480 (from American Type Culture Collection, Manassas, VA), the ovarian carcinoma cell line A2780 (from Sigma-Aldrich) and the epidermal carcinoma-derived cell line KB-3-1 (generously donated by D.W. Shen, Bethesda, USA). All cells were grown in RMPI 1640 supplemented with $10 \%$ fetal bovine serum (FCS), with the exception of SW480 cells with were cultivated in minimal essential medium with $10 \%$ FCS. Cultures were regularly checked for Mycoplasma contamination.

\subsection{MTT assays}

To determine cell viability, cells were plated $\left(2 \times 10^{3}\right.$ cells in $100 \mu \mathrm{L} /$ well $)$ in 96 -well plates and allowed to recover for $24 \mathrm{~h}$. Stock solutions (in DMSO) of the test compounds (APTSC, PTSC, STSC, 1a, 2a, 1b) were diluted in complete culture medium and added to the plates $(100 \mu \mathrm{L} /$ well). The maximum DMSO content did not exceed $0.5 \%$. Stock solution of the $\mathrm{V}(\mathrm{V})-\mathrm{STSC}$ complex was prepared by addition of $\mathrm{NaVO}_{3}$ in water to STSC in DMSO at a 1:1 metal-to-ligand ratio, followed by subsequent dilution with cell culture medium. After 72 $\mathrm{h}$ drug treatment, the proportion of viable cells was determined by the colorimetric MTT microculture assay following the manufacturer's recommendations (EZ4U, Biomedica, Vienna, Austria). 


\section{Abbreviations}

$1 a$

$1 \mathrm{~b}$

$2 a$

acac

APTSC

CT

CW

$\delta$

$D_{7.4}$

DMSO

Dp44mT

$\varepsilon$

ESI-MS

FCS

HEPES

MTT

PTSC

SQD

SSC

STSC

TSC

Triapine

UV-vis (2-formylpyridine N,N-dimethylthiosemicarbazonato)dioxovanadium(V)

(3-amino-2-formylpyridine N,N-

dimethylthiosemicarbazonato)dioxovanadium(V)

(acetylacetonato(2-formylpyridine N,N-

dimethylthiosemicarbazonato)oxovanadium(IV)

acetylacetonate

3-aminopyridine-2-carboxaldehyde N,N-dimethylthiosemicarbazone

charge transfer

continuous-wave

chemical shift

distribution coefficient at $\mathrm{pH} 7.4$

dimethyl sulfoxide

di-2-pyridylketone-4,4-dimethyl-3-thiosemicarbazone

molar absorptivity

electrospray ionization mass spectrometry

fetal bovine serum

4-(2-hydroxyethyl)-1-piperazineethanesulfonic acid

3-(4,5-dimethyl-2-thiazolyl)-2,5-diphenyl-2H-tetrazolium bromide

pyridine-2-carboxaldehyde N,N-dimethylthiosemicarbazone

average square deviation

salicylaldehyde semicarbazone

salicylaldehyde thiosemicarbazone

thiosemicarbazone

3-aminopyridine-2-carboxaldehyde thiosemicarbazone

UV-visible

\section{Acknowledgments}

This work has been supported by the Hungarian Research Foundation OTKA project PD103905, the Hungarian-Austrian Action Foundation (880̈u4) and the Austrian Science Fund (FWF) grant P22072-B11. 


\section{References}

[1] D.X. West, S.B. Padhye, P.B. Sonawane, Struct. Bonding (Berlin) 76 (1991) 1-50.

[2] J.R. Dilworth, R. Hueting, Inorg. Chim. Acta 389 (2012) 389, 3-15.

[3] J. Shao, B. Zhou, A.J. Di Bilio, L. Zhu, T. Wang, C.Q.J. Shih, Y. Yen, Mol. Cancer Ther. 5 (2006) 586-592.

[4] C.M. Nutting, C.M.L van Herpen, A.B. Miah, S.A. Bhide, J.P. Machiels, J. Buter, C. Kelly, D. de Raucourt, K.J. Harrington, Annals Oncol. 20 (2009) 1275-1279.

[5] T.B. Chaston, D.B. Lovejoy, R.N. Watts, D.R. Richardson, Clin. Cancer Res. 9 (2003) 402-414.

[6] Y. Ays, M.J.C. Long, J. Stubbe, J. Biol Chem. 287 (2012) 35768-35778.

[7] C.R. Kowol, R. Trondl, P. Heffeter, V.B. Arion, M.A. Jakupec, A. Roller, M. Galanski, W. Berger, B.K. Keppler, J. Med. Chem. 52 (2009) 5032-2043.

[8] E.A. Enyedy, N.V. Nagy, E. Zsigo, C.R. Kowol, V.B. Arion, B.K. Keppler, T. Kiss, Eur. J. Inorg. Chem. (2010) 1717-1728.

[9] E.A. Enyedy, M.F. Primik, C.R. Kowol, V.B. Arion, T. Kiss, B.K. Keppler, Dalton Trans. 40 (2011) 5895-5905.

[10] Y. Yu, D.S. Kalinowski, Z. Kovacevic, A.R. Siafakas, P.J. Jansson, C. Stefani, D.B. Lovejoy, P.C. Sharpe, P.V. Bernhardt, D.R. Richardson, J. Med. Chem. 52 (2009) 5271-5294.

[11] M. Whitnall, J. Howard, P. Ponka, D.R. Richardson, P. Natl. Acad. Sci. USA 103 (2006) 14901-14906.

[12] P.J. Jansson, T. Yamagishi, A. Arvind, N. Seebacher, E. Gutierrez, A. Stacy, S. Maleki, D. Sharp, S. Sahni, D.R. Richardson, J. Biol. Chem. 290 (2015) 9588-9603.

[13] B.M. Paterson, P.S. Donnelly, Chem. Soc. Rev. 40 (2011) 3005-3018.

[14] C.R. Kowol, P. Heffeter, W. Miklos, L. Gille, R. Trondl, L. Cappellacci, W. Berger, B.K. Keppler, J. Biol. Inorg. Chem. 17 (2012) 409-423.

[15] D.X. West, A.E. Liberta, S.B. Padhye, R.C. Chikate, P.B. Sonawane, A.S. Kumbhar, R.G. Yerande, Coord. Chem. Rev. 123 (1993) 49-71.

[16] J. Shao, W.G. Bao, H. Tian, B. Li, X.F. Zhao, X. Qiao, J.Y. Xu, Dalton Trans. 43 (2014) 1663-1671.

[17] H. Beraldo, D. Gambino, Mini Rev. Med. Chem. 4 (2004) 31-39. 
[18] T.S. Lobana, R. Sharma, G. Bawa, S. Khanna, Coord. Chem. Rev. 253 (2009) 977-1055.

[19] S.A. Elsayed, A.M. El-Hendawy, S.I. Mostafa, B.J. Jean-Claude, M. Todorova, I.S. Butler, Bioinorg. Chem. Appl. (2010) Article ID 149149.

[20] N.A. Lewis, F. Liu, L. Seymour, A. Magnusen, T.R. Erves, J. Faye Arca, F.A. Beckford, R. Venkatraman, A. González-Sarrías, F.R. Fronczek, D.G. VanDerveer, N.P. Seeram, A. Liu, W.L. Jarrett, A.A. Holder, Eur. J. Inorg. Chem. (2012) 664-677.

[21] I.C. Mendes, L.M. Botion, A.V.M. Ferreira, E.E. Castellano, H. Beraldo, Inorg. Chim. Acta 362 (2009) 414-420.

[22] L.S. Vojinovic-Jesic, V.M. Leovac, M.M. Lalovic, V.I. Cesljevic, L.S. Jovanovic, M.V. Rodic, V. Divjakovic, J. Serb. Chem. Soc. 76 (2011) 865-877.

[23] M. Sutradhar, T.R. Barman, G. Mukherjee, M.G.B. Drew, S. Ghosh, Inorg. Chim. Acta 363 (2010) 3376-3383.

[24] P.I. da S. Maia, F.R. Pavan, C.Q.F. Leite, S.S. Lemos, G.F. de Sousa, A.A. Batista, O.R. Nascimento, J. Ellena, E.E. Castellano, E. Niquet, Polyhedron 28 (2009) 398-406.

[25] É.A. Enyedy, É. Zsigó, N.V. Nagy, C.R. Kowol, A. Roller, B.K. Keppler, T. Kiss, Eur. J. Inorg. Chem. (2012) 4036-4047.

[26] D. Wang, M. Ebel, C. Schulzke, C. Grüning, S.K.S. Hazari, D. Rehder, Eur. J. Inorg. Chem. (2001) 935-942.

[27] T.S. Smith, R. LoBrutto, V.L. Pecoraro, Coord. Chem. Rev. 228 (2002) 1-18.

[28] N.D. Chasteen, in: Biological Magnetic Resonance (L.J. Berliner, J. Reuben, Eds), Vol. 3, Plenum Press, New York, 1981, pp. 53-119.

[29] S. Gorelsky, G. Micera, E. Garribba, Chem. Eur. J. 16 (2010) 8167-8180.

[30] J. García-Tojal, B. Donnadieu, J.P. Costes, J.L. Serra, L. Lezama, T. Rojo, Inorg. Chim. Acta 333 (2002) 132-137.

[31] R. McElhinney, J. Chem. Soc. C (1966) 950-955.

[32] K. Oyaizu, E.L. Dewi, E. Tsuchida, J. Electroanal. Chem. 498 (2001) 136-141.

[33] M. Pessôa, G.F.S. Andrade, V.R. Paoli Monteiro, M.L.A. Temperini, Polyhedron 20 (2001) 3133-3141.

[34] A.W. Addison, T.N. Rao, J. Reedijk, J. van Rijn, G.C. Verschoor, J. Chem. Soc. Dalton Trans. (1984) 1349-1356.

[35] B. Koo, Y. Jang, U. Lee, Bull. Korean Chem. Soc. 24 (2003) 1014-1016. 
[36] P. Heffeter, C. Pirker, C.R. Kowol, G. Herrman, R. Dornetshuber, W. Miklos, U. Jungwirth, G. Koellensperger, B.K. Keppler, W. Berger, Biochem. Pharmacol. 83 (2012) 1623-1633.

[37] E.A. Enyedy, G.M. Bognar, N.V. Nagy, T. Jakusch, T. Kiss, D. Gambino, Polyhedron 67 (2014) 242-252.

[38] J. Lu, H. Guo, X. Zeng, Y. Zhang, P. Zhao, J. Jiang, L. Zang, J. Inorg. Biochem. 112 (2012) 39-48.

[39] P. Ying, P. Zeng, J. Lu, H. Chen, X. Liao, N. Yang, Chem. Biol. Drug Des. (2015) doi: $10.1111 /$ cbdd. 12535

[40] P. Gans, A. Sabatini, A. Vacca, Talanta 43 (1996) 1739-1753.

[41] I. Nagypal, I. Fabian, Inorg. Chim. Acta 61 (1982) 109-113.

[42] SAINT-Plus, version 7.68a and APEX2; Bruker-Nonius AXS Inc.: Madison, WI, USA 2008.

[43] G.M. Sheldrick, Acta Crystallogr. A64 (2008) 112-122.

[44] M.N. Burnett, G.K. Johnson, ORTEP III, Report ORNL-6895; Oak Ridge National Laboratory; Oak Ridge, TN, 1996.

[45] H.M. Irving, M.G. Miles, L.D. Pettit, Anal. Chim. Acta 38 (1967) 475-488.

[46] SCQuery, The IUPAC Stability Constants Database, Academic Software (Version 5.5), Royal Society of Chemistry, 1993-2005.

[47] L. Zékány, I. Nagypál, in: Computational Methods for the Determination of Stability Constants, Ed. D. L. Leggett, Plenum Press, New York, 1985, pp. 291-353.

[48] E. Kiss, K. Kawabe, A. Tamura, T. Jakusch, H. Sakurai, T. Kiss, J. Inorg. Biochem. 95 (2003) 69-76.

[49] K. Elvingson, A. González Baró, L. Pettersson, Inorg. Chem. 35 (1996) 3388-3393.

[50] A. Rockenbauer, T. Szabó-Plánka, Zs. Árkosi, L. Korecz, J. Am. Chem. Soc. 123 (2001) 7646-7654.

[51] A. Rockenbauer, L. Korecz, Appl. Magn. Reson. 10 (1996) 29-43. 
Table 1 Proton dissociation constants $\left(\mathrm{p} K_{\mathrm{a}}\right)$ and $\log D_{7.4}$ values of the studied TSC ligands as well as overall $(\log \beta)$, stepwise and conditional stability constants for their $\mathrm{V}(\mathrm{IV}) \mathrm{O}$ complexes $\left\{T=25.0^{\circ} \mathrm{C}, I=0.10 \mathrm{M}(\mathrm{KCl})\right.$ in $\left.30 \%(\mathrm{w} / \mathrm{w}) \mathrm{DMSO} / \mathrm{H}_{2} \mathrm{O}\right\} .^{\mathrm{a}}$

\begin{tabular}{lrrrr}
\hline & \multicolumn{1}{c}{ Triapine } & \multicolumn{1}{c}{ APTSC } & \multicolumn{1}{c}{ PTSC } & \multicolumn{1}{c}{ STSC } \\
\hline $\mathrm{p} K_{1}$ & $3.92^{\mathrm{b}}$ & $4.31^{\mathrm{b}}$ & $3.38^{\mathrm{b}}$ & $8.89^{\mathrm{c}}$ \\
$\mathrm{p} K_{2}$ & $10.78^{\mathrm{b}}$ & $10.29^{\mathrm{b}}$ & $10.54^{\mathrm{b}}$ & $12.59^{\mathrm{c}}$ \\
$\log D_{7.4}$ & $+0.85^{\mathrm{c}}$ & $+1.30(8)$ & $+1.11(15)$ & $+1.74^{\mathrm{c}}$ \\
$\log \beta[\mathrm{V}(\mathrm{IV}) \mathrm{O}(\mathrm{LH})]$ & - & - & - & $20.55(2)$ \\
$\log \beta[\mathrm{V}(\mathrm{IV}) \mathrm{O}(\mathrm{L})]$ & $8.50(8)$ & $10.30(4)$ & $10.83(2)$ & $16.67(1)$ \\
$\log \beta\left[\mathrm{V}(\mathrm{IV}) \mathrm{O}(\mathrm{L}) \mathrm{H}_{-1}\right]$ & $3.21(9)$ & $4.14(12)$ & $4.74(5)$ & $9.79(1)$ \\
$\mathrm{p} K[\mathrm{~V}(\mathrm{IV}) \mathrm{O}(\mathrm{L})]$ & 5.29 & 6.16 & 6.09 & 6.88 \\
fitting parameter $(\mathrm{mL})$ & $4.90 \times 10^{-3}$ & $3.25 \times 10^{-3}$ & $2.90 \times 10^{-3}$ & $3.08 \times 10^{-3}$ \\
$\log K^{\prime}[\mathrm{V}(\mathrm{IV}) \mathrm{O}(\mathrm{L})]^{\mathrm{d}}$ & 7.23 & 8.67 & 9.02 & 10.61 \\
$\operatorname{predominant~complex}{ }^{\mathrm{e}}$ & $\left(\left[\mathrm{V}(\mathrm{IV}) \mathrm{O}_{2}(\mathrm{OH})_{5}\right]\right)$ & {$\left[\mathrm{V}(\mathrm{IV}) \mathrm{O}\left(\mathrm{LH}_{-1}\right)\right]$} & {$\left[\mathrm{V}(\mathrm{IV}) \mathrm{O}\left(\mathrm{LH}_{-1}\right)\right]$} & {$\left[\mathrm{V}(\mathrm{IV}) \mathrm{O}\left(\mathrm{LH}_{-1}\right)\right]$} \\
\hline
\end{tabular}

${ }^{a}$ Uncertainties (SD) of the last digits are shown in parentheses determined for the TSCs studied in the present work. Charges of the metal complexes are omitted for clarity.

${ }^{\mathrm{b}}$ Taken from [8].

${ }^{\mathrm{c}}$ Taken from [25].

${ }^{\mathrm{d}}$ Conditional stability constants at $\mathrm{pH}=7.4 ; K^{\prime}=\beta[\mathrm{V}(\mathrm{IV}) \mathrm{O}(\mathrm{L})] \times\left(1+\beta\left[\mathrm{V}(\mathrm{IV}) \mathrm{O}(\mathrm{L}) \mathrm{H}_{-1}\right] /\left[\mathrm{H}^{+}\right] /\right.$

$\beta[\mathrm{V}(\mathrm{IV}) \mathrm{O}(\mathrm{L})]) /\left(1+\left[\mathrm{H}^{+}\right] \times \beta_{\mathrm{HL}}+\left[\mathrm{H}^{+}\right]^{2} \times \beta_{\mathrm{H} 2 \mathrm{~L}}\right)$.

${ }^{\mathrm{e}}$ at $\mathrm{pH}=7.4 ; c_{\mathrm{V}(\mathrm{IV}) \mathrm{O}}=1.0 \mathrm{mM} ; \mathrm{V}(\mathrm{IV}) \mathrm{O}: \mathrm{L}=1: 1$. 
Table 2 Isotropic EPR parameters obtained for the V(IV)O - TSC complexes calculated from the two-dimensional simulation of EPR spectra $\left\{T=25.0^{\circ} \mathrm{C}, I=0.10 \mathrm{M}(\mathrm{KCl})\right.$ in $30 \%(\mathrm{w} / \mathrm{w})$ $\left.\mathrm{DMSO} / \mathrm{H}_{2} \mathrm{O}\right\}^{\text {a }}$

\begin{tabular}{clllllc}
\hline ligand & \multicolumn{1}{c}{ species } & $\boldsymbol{g}_{\mathbf{0}}$ & $\boldsymbol{A}_{\mathbf{0}} / \times \mathbf{1 0}^{-4} \mathbf{c m}^{-\mathbf{1}}$ & $\boldsymbol{\alpha} / \mathbf{G}$ & $\boldsymbol{\beta} / \mathbf{G}$ & $\boldsymbol{\gamma} / \mathbf{G}$ \\
\hline- & $\mathrm{V}(\mathrm{IV}) \mathrm{O}^{2+}$ & $1.9616(2)$ & $104.5(2)$ & $18.7(1)$ & $3.5(1)$ & $1.8(1)$ \\
Triapine & {$[\mathrm{V}(\mathrm{IV}) \mathrm{O}(\mathrm{L})]^{+}$} & $1.9703(8)$ & $87.8(8)$ & $23(2)$ & $5(1)$ & $2.8(3)$ \\
Triapine & {$\left[\mathrm{V}(\mathrm{IV}) \mathrm{O}(\mathrm{L}) \mathrm{H}_{-1}\right]$} & $1.972(2)$ & $82.9(4)$ & $26(7)$ & $3(2)$ & $3(1)$ \\
APTSC & {$[\mathrm{V}(\mathrm{IV}) \mathrm{O}(\mathrm{L})]^{+}$} & $1.9709(9)$ & $87.4(1)$ & $23(3)$ & $5(2)$ & $3.3(1)$ \\
APTSC & {$\left[\mathrm{V}(\mathrm{IV}) \mathrm{O}(\mathrm{L}) \mathrm{H}_{-1}\right]$} & $1.971(2)$ & $79.1(3)$ & $26(7)$ & $3(2)$ & $3(1)$ \\
PTSC & {$[\mathrm{V}(\mathrm{IV}) \mathrm{O}(\mathrm{L})]^{+}$} & $1.9702(2)$ & $88.7(6)$ & $19(3)$ & $4(1)$ & $2.3(5)$ \\
PTSC & {$\left[\mathrm{V}(\mathrm{IV}) \mathrm{O}(\mathrm{L}) \mathrm{H}_{-1}\right]$} & $1.9711(4)$ & $83.1(6)$ & $19(7)$ & $3(2)$ & $2(1)$ \\
STSC & {$[\mathrm{V}(\mathrm{IV}) \mathrm{O}(\mathrm{L})]$} & $1.9717(7)$ & $87.6(7)$ & $21(1)$ & $3(1)$ & $2.0(3)$ \\
\hline
\end{tabular}

${ }^{a}$ Uncertainties (SD) of the last digits are shown in parentheses determined in the present work.

Table 3 Anisotropic EPR parameters obtained for the V(IV)O - PTSC complexes $\{T=77 \mathrm{~K}$, $I=0.10 \mathrm{M}(\mathrm{KCl})$ in $\left.30 \%(\mathrm{w} / \mathrm{w}) \mathrm{DMSO} / \mathrm{H}_{2} \mathrm{O}\right\}$. $^{\mathrm{a}}$

\begin{tabular}{|c|c|c|c|c|c|c|}
\hline & $g_{\|}$ & $g_{\perp}$ & $\begin{array}{c}A_{\|} \\
/ \times 10^{-4} \mathbf{c m}^{-1}\end{array}$ & $\begin{array}{c}A_{\perp} \\
/ \times 10^{-4} \mathbf{c m}^{-1}\end{array}$ & $g_{0 \text { 'calc }}{ }^{b}$ & $\begin{array}{c}A_{\mathrm{o}^{\prime} \mathrm{calc}} \mathrm{c} \\
/ \times \mathbf{1 0}^{-4} \mathrm{~cm}^{-1}\end{array}$ \\
\hline $\mathrm{V}(\mathrm{IV}) \mathrm{O}^{2+}$ & 1.9325 & 1.9743 & 179.7 & 67.5 & 1.9604 & 104.9 \\
\hline$[\mathrm{V}(\mathrm{IV}) \mathrm{O}(\mathrm{L})]^{+}(1)$ & 1.9525 & 1.9801 & 158.2 & 54.4 & 1.9709 & 89.0 \\
\hline$[\mathrm{V}(\mathrm{IV}) \mathrm{O}(\mathrm{L})]^{+}(2)$ & 1.9470 & 1.9788 & 164.5 & 59.6 & 1.9672 & 94.6 \\
\hline$\left[\mathrm{V}(\mathrm{IV}) \mathrm{O}(\mathrm{L}) \mathrm{H}_{-1}\right](1)$ & 1.9546 & 1.9801 & 153.6 & 50.5 & 1.9716 & 84.9 \\
\hline$\left[\mathrm{V}(\mathrm{IV}) \mathrm{O}(\mathrm{L}) \mathrm{H}_{-1}\right](2)$ & 1.9683 & 1.9823 & 143.6 & 45.6 & 1.9776 & 78.3 \\
\hline
\end{tabular}

${ }^{\text {a }}$ The experimental error was \pm 0.001 for $g_{\|}, \pm 0.0005$ for $g_{\perp}, \pm 0.5 \times 10^{-4} \mathrm{~cm}^{-1}$ for $A_{\|}$, and \pm 0.2

$\times 10^{-4} \mathrm{~cm}^{-1}$ for $A \perp$.

${ }^{\mathrm{b}} g_{0, \text { calc }}=\left(g_{\|}+2 g_{\perp}\right) / 3$.

${ }^{\mathrm{c}} A_{0, \text { calc }}=\left(A_{\|}+2 A \perp\right) / 3$. 
Table 4 Stability and protonation constants determined for the species formed in the $\mathrm{V}(\mathrm{V}) \mathrm{O}_{2}$ - TSC systems and their chemical shifts $\left(\delta\left({ }^{51} \mathrm{~V}\right)\right)\left\{T=25.0^{\circ} \mathrm{C}, I=0.10 \mathrm{M}(\mathrm{KCl})\right.$ in $30 \%(\mathrm{v} / \mathrm{v})$ DMSO, $\left.60 \%(\mathrm{v} / \mathrm{v}) \mathrm{H}_{2} \mathrm{O}, 10 \%(\mathrm{v} / \mathrm{v}) \mathrm{D}_{2} \mathrm{O}\right\}$. $^{\mathrm{a}}$

\begin{tabular}{|c|c|c|}
\hline ligand & equilibrium & constant \\
\hline- & $\begin{array}{ll}\mathrm{HVO}_{4}^{2-}+\mathrm{H}^{+} \rightleftharpoons & \mathrm{H}_{2} \mathrm{VO}_{4}^{-} \\
-561 \mathrm{ppm} & -536 \mathrm{ppm}\end{array}$ & $\log K=9.36(2)$ \\
\hline APTSC & $\begin{aligned} \mathrm{H}_{2} \mathrm{VO}_{4}^{-}+\mathrm{HL}+\mathrm{H}^{+} & \rightleftharpoons\left[\mathrm{VO}_{2}(\mathrm{~L})\right]+2 \mathrm{H}_{2} \mathrm{O} \\
& -416 \mathrm{ppm}\end{aligned}$ & $\log K=3.08(3)$ \\
\hline PTSC & $\begin{aligned} \mathrm{H}_{2} \mathrm{VO}_{4}^{-}+\mathrm{HL}+\mathrm{H}^{+} & \rightleftharpoons\left[\mathrm{VO}_{2}(\mathrm{~L})\right]+2 \mathrm{H}_{2} \mathrm{O} \\
& -421 \mathrm{ppm}\end{aligned}$ & $\log K=3.34(3)$ \\
\hline STSC & $\begin{array}{c}{\left[\mathrm{VO}_{2}(\mathrm{~L})\right]^{-}(1)+\mathrm{H}^{+} \rightleftharpoons} \\
-449 \mathrm{ppm} \\
-502 \mathrm{ppm}\end{array}$ & $\log K=3.56(1)$ \\
\hline STSC & $\begin{array}{cc}{\left[\mathrm{VO}_{2}(\mathrm{~L}) \mathrm{H}_{-1}\right]^{2-}+\mathrm{H}^{+} \rightleftharpoons} & {\left[\mathrm{VO}_{2}(\mathrm{~L})\right]^{-}(2)} \\
-539 \mathrm{ppm} & -577 \mathrm{ppm}\end{array}$ & $\log K=9.95(2)$ \\
\hline STSC & $\mathrm{H}_{2} \mathrm{VO}_{4}^{-}+\mathrm{H}_{2} \mathrm{~L} \rightleftharpoons\left[\mathrm{VO}_{2}(\mathrm{~L})\right]^{-}(1)+2 \mathrm{H}_{2} \mathrm{O}$ & $\log K=5.42(5)$ \\
\hline STSC & $\mathrm{H}_{2} \mathrm{VO}_{4}^{-}+\mathrm{H}_{2} \mathrm{~L} \rightleftharpoons\left[\mathrm{VO}_{2}(\mathrm{~L})\right]^{-}(2)+2 \mathrm{H}_{2} \mathrm{O}$ & $\log K=4.57(5)$ \\
\hline
\end{tabular}


Table 5 Selected bond lengths, angles and torsions for 1a, 2a and PTSC

\begin{tabular}{|c|c|c|c|}
\hline & $\mathbf{1 a}$ & $2 \mathbf{a}$ & PTSC $^{b}$ \\
\hline $\mathrm{V}(\mathrm{IV})-\mathrm{O} 1[\AA \mathbf{A}]$ & & $1.984(1)$ & \\
\hline 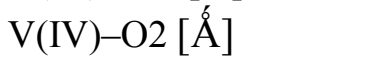 & & $2.155(1)$ & \\
\hline 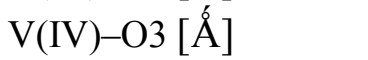 & & $1.608(1)$ & \\
\hline 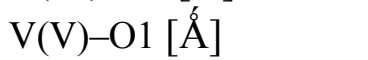 & $1.608(2)$ & & \\
\hline $\mathrm{V}(\mathrm{V})-\mathrm{O} 2[\AA ̊ x]$ & $1.617(2)$ & & \\
\hline $\mathrm{V}-\mathrm{S} 1[\AA \hat{A}]$ & $2.3725(8)$ & $2.4026(6)$ & \\
\hline $\mathrm{V}-\mathrm{N} 1[\AA \grave{A}]$ & $2.105(2)$ & $2.150(1)$ & \\
\hline 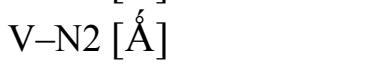 & $2.149(2)$ & $2.074(1)$ & \\
\hline $\mathrm{S} 1-\mathrm{C} 7[\AA \grave{A}]$ & $1.737(3)$ & $1.751(2)$ & $1.686(1)$ \\
\hline $\mathrm{N} 2-\mathrm{N} 3[\AA \bar{A}]$ & $1.355(3)$ & $1.365(2)$ & $1.359(1)$ \\
\hline 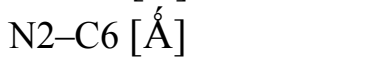 & $1.291(3)$ & $1.294(2)$ & $1.294(1)$ \\
\hline 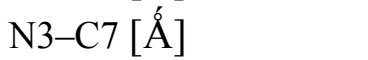 & $1.325(3)$ & $1.334(2)$ & $1.373(1)$ \\
\hline 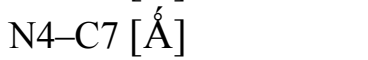 & $1.328(4)$ & $1.341(2)$ & $1.342(1)$ \\
\hline C5-C6 [Á] & $1.439(4)$ & $1.453(2)$ & $1.466(2)$ \\
\hline S-V-N2 [deg] & $76.91(6)$ & $79.08(4)$ & \\
\hline N1-V-N2 [deg] & $74.67(8)$ & $77.42(5)$ & \\
\hline S-V-N1 [deg] & $151.38(7)$ & $154.07(4)$ & \\
\hline N2-V-O1 [deg] & $121.2(1)$ & $163.89(5)$ & \\
\hline $\mathrm{N} 2-\mathrm{V}-\mathrm{O} 2[\mathrm{deg}]$ & 129.1(1) & & \\
\hline $\mathrm{N} 1-\mathrm{V}-\mathrm{O} 1[\mathrm{deg}]$ & $97.3(1)$ & & \\
\hline $\mathrm{N} 1-\mathrm{V}-\mathrm{O} 2$ [deg] & $97.4(1)$ & & \\
\hline $\mathrm{O} 2-\mathrm{V}-\mathrm{O} 3[\mathrm{deg}]$ & & $171.86(5)$ & \\
\hline C6-N2-N3-C7 [deg] & $-178.7(2)$ & $-171.3(1)$ & $177.6(1)$ \\
\hline N2-N3-C7-S [deg] & $-0.2(3)$ & $4.0(2)$ & $-4.9(1)$ \\
\hline
\end{tabular}

${ }^{a}$ Uncertainties (SD) of the last digits are shown in parentheses.

${ }^{\mathrm{b}}$ Taken from [7]. 
Table 6 In vitro cytotoxicity $\left(\mathrm{IC}_{50}\right.$ values in $\left.\mathrm{nM}\right)$ of $\mathbf{1 a}, \mathbf{1 b}$, and $\mathbf{2 a}$ in comparison to their metal-free ligands were measured in human cancer cell lines.

\begin{tabular}{llll}
\hline & KB-3-1 & SW480 & A2780 \\
\hline 1a & $67 \pm 37$ & $>500$ & $3.3 \pm 9$ \\
2a & $60 \pm 34$ & $330 \pm 4$ & $2.5 \pm 4$ \\
PTSC & $92 \pm 5$ & $310 \pm 13$ & $2.5 \pm 3$ \\
1b & $1000 \pm 7$ & $700 \pm 4$ & $600 \pm 17$ \\
APTSC & $750 \pm 30$ & $400 \pm 3$ & $340 \pm 6$ \\
Triapine & $2800 \pm 20^{\mathrm{a}}$ & $400 \pm 50^{\mathrm{b}}$ & N/A \\
\hline
\end{tabular}

${ }^{\mathrm{a}}$ Taken from [36].

${ }^{\mathrm{b}}$ Taken from [14]. 


\section{Figures/Charts and Legends}<smiles>NC(=S)N/N=C/c1ncccc1N</smiles><smiles>CN(C)C(=S)N/N=C/c1ncccc1N</smiles><smiles>CN(C)C(=S)N/N=C/c1ccccn1</smiles><smiles>NC(=S)N/N=C/c1ccccc1O</smiles>

Chart 1. Ligands used in this study: Triapine (3-AP) $=3$-aminopyridine-2-carboxaldehyde thiosemicarbazone; APTSC $=3$-aminopyridine-2-carboxaldehyde $\mathrm{N}, \mathrm{N}$-dimethylthiosemicarbazone; PTSC = pyridine-2-carboxaldehyde $\mathrm{N}, \mathrm{N}$-dimethylthiosemicarbazone; $\mathrm{STSC}=$ salicylaldehyde thiosemicarbazone.<smiles>[R]C=NN=C(S)N([R2])[R]</smiles>

Chart 2. Tautomerism of thiosemicarbazones.<smiles></smiles>

1a $\mathrm{R}_{1}=\mathrm{H} ;\left[\mathrm{V}(\mathrm{V}) \mathrm{O}_{2}(\mathrm{~L})\right]$ formed with PTSC 1b $\mathrm{R}_{1}=\mathrm{NH}_{2} ;\left[\mathrm{V}(\mathrm{V}) \mathrm{O}_{2}(\mathrm{~L})\right]$ formed with APTSC

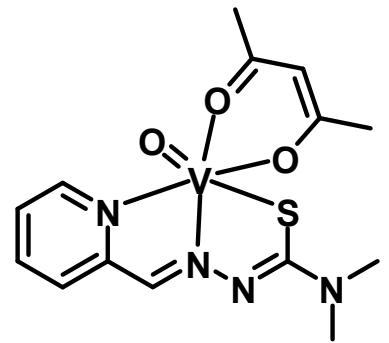

2a [V(IV)O(L)(acac)] formed with PTSC

Chart 3. Structures of the synthesized complexes 1a, 1b and 2a. 

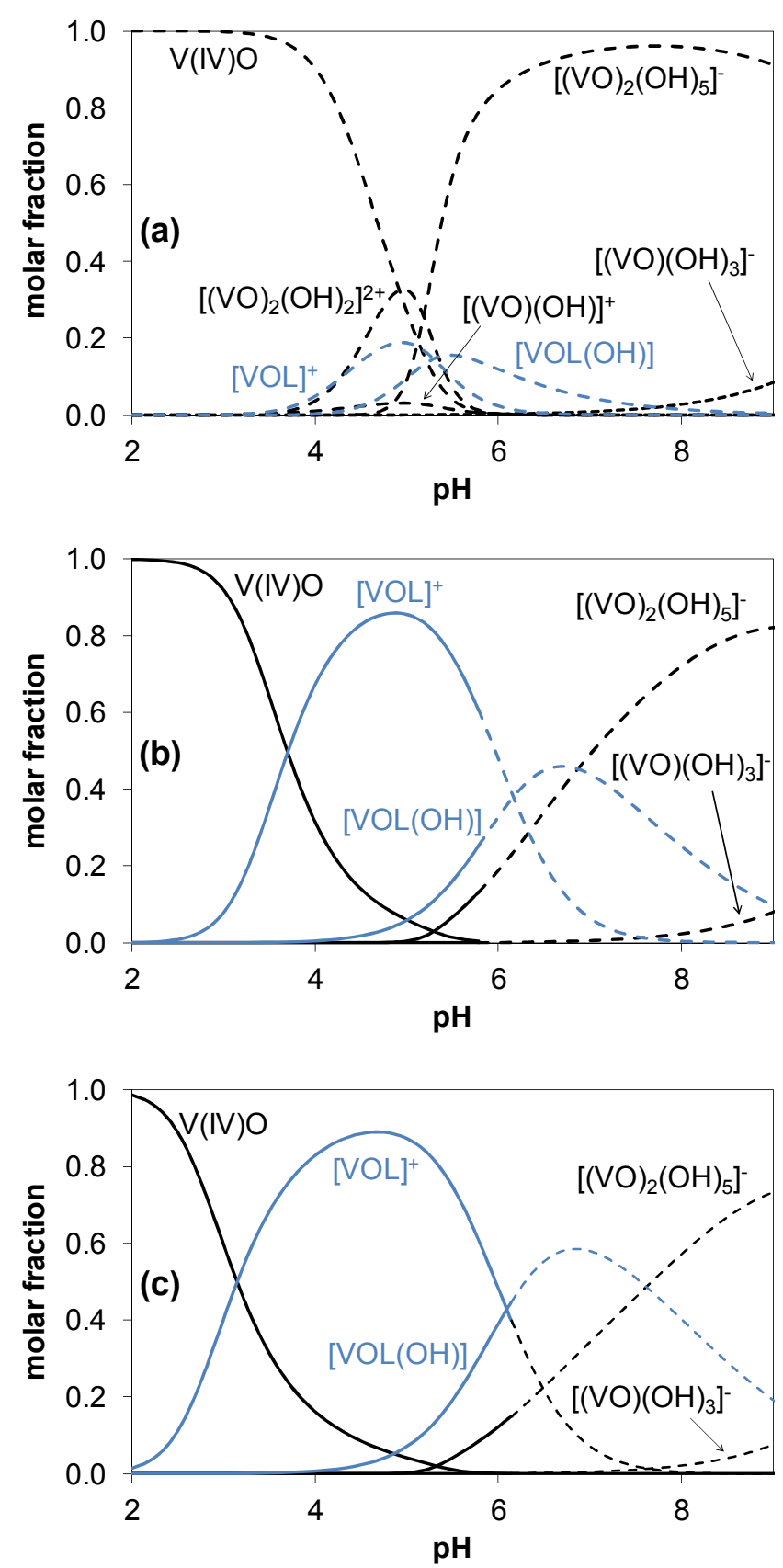

Fig. 1. Representative concentration distribution diagrams for $\mathrm{V}(\mathrm{IV}) \mathrm{O}$ complexes formed in the V(IV)O - Triapine (a), APTSC (b) and PTSC (c) systems plotted against the pH calculated on the basis of the pH-potentiometric results. $\left\{\mathrm{V}(\mathrm{IV}) \mathrm{O}: \mathrm{L}=1: 1 ; c_{\text {ligand }}=2.0 \mathrm{mM} ; T=25.0{ }^{\circ} \mathrm{C}, I=0.10 \mathrm{M}\right.$ $(\mathrm{KCl})$ in $30 \%(\mathrm{w} / \mathrm{w}) \mathrm{DMSO} / \mathrm{H}_{2} \mathrm{O}$. 3 Dashed lines indicate the $\mathrm{pH}$ range where significant amounts of hydrolyzed V(IV)O species are formed. 

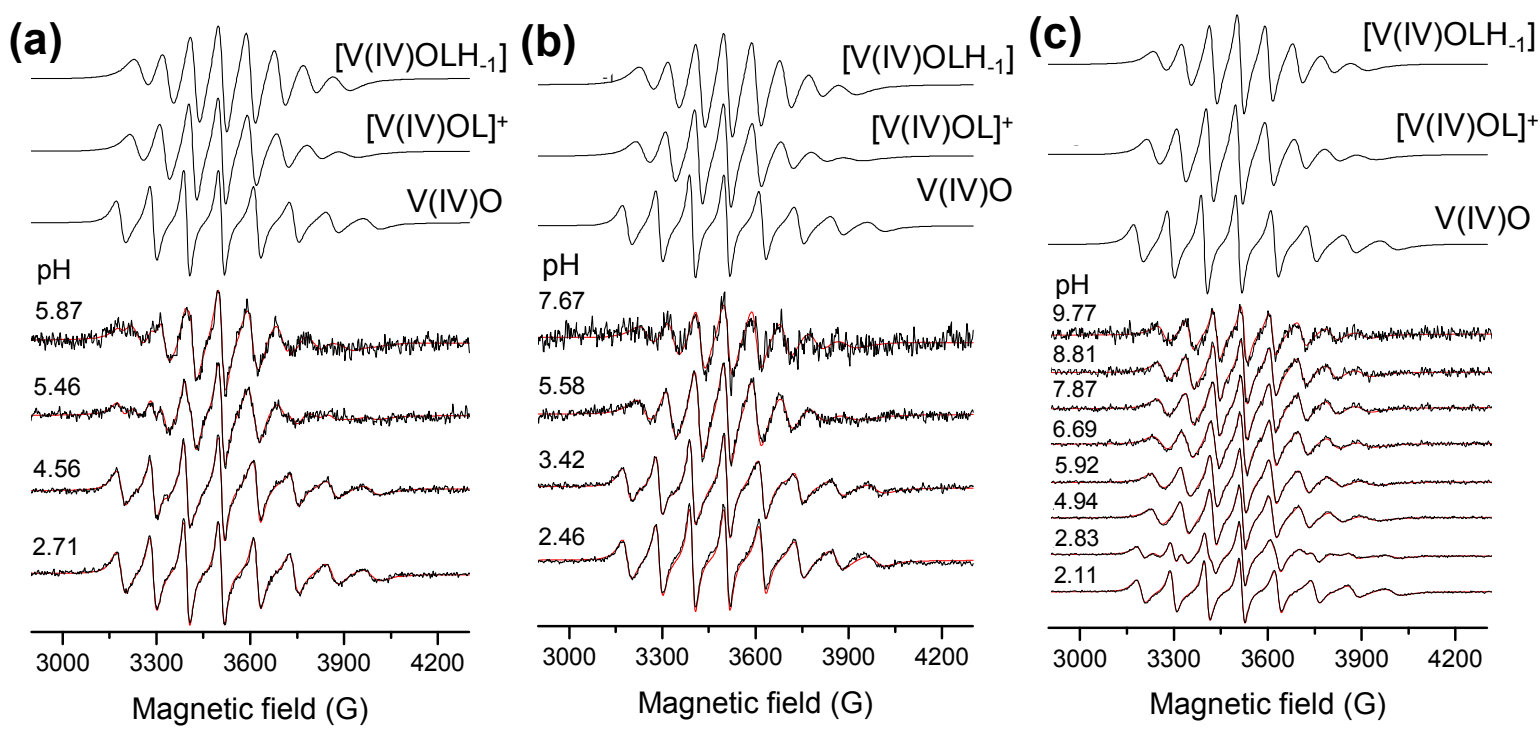

Fig. 2. Experimental (black) and simulated (red) isotropic EPR spectra recorded for the V(IV)O Triapine (a), APTSC (b) and PTSC (c) systems together with the calculated component EPR spectra of the various species. Spectral intensities have been normalized for better comparison. $\left\{c_{\text {ligand }}=1.0 \mathrm{mM}\right.$; $\mathrm{V}(\mathrm{IV}) \mathrm{O}: \mathrm{L}=1: 2,1: 2$ and 1:4 for APTSC, PTSC and Triapine, respectively; $T=25.0^{\circ} \mathrm{C}, I=0.10 \mathrm{M}$ $(\mathrm{KCl})$ in $\left.30 \%(\mathrm{w} / \mathrm{w}) \mathrm{DMSO} / \mathrm{H}_{2} \mathrm{O}.\right\}$

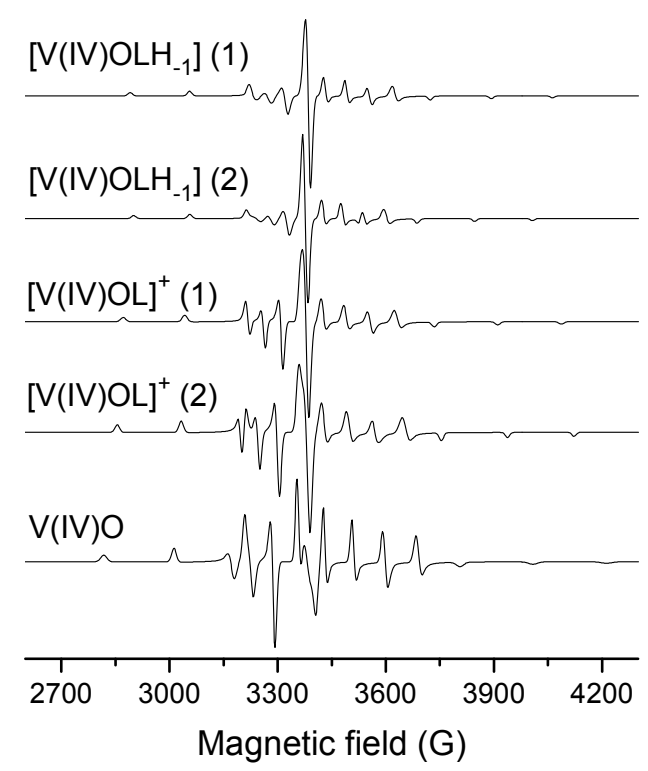

Fig. 3. Calculated component anisotropic EPR spectra of $\mathrm{V}(\mathrm{IV}) \mathrm{O}$ and various isomeric species formed in the V(IV)O - PTSC system. $\left\{T=77 \mathrm{~K}, I=0.10 \mathrm{M}(\mathrm{KCl})\right.$ in $\left.30 \%(\mathrm{w} / \mathrm{w}) \mathrm{DMSO} / \mathrm{H}_{2} \mathrm{O}.\right\}$ 

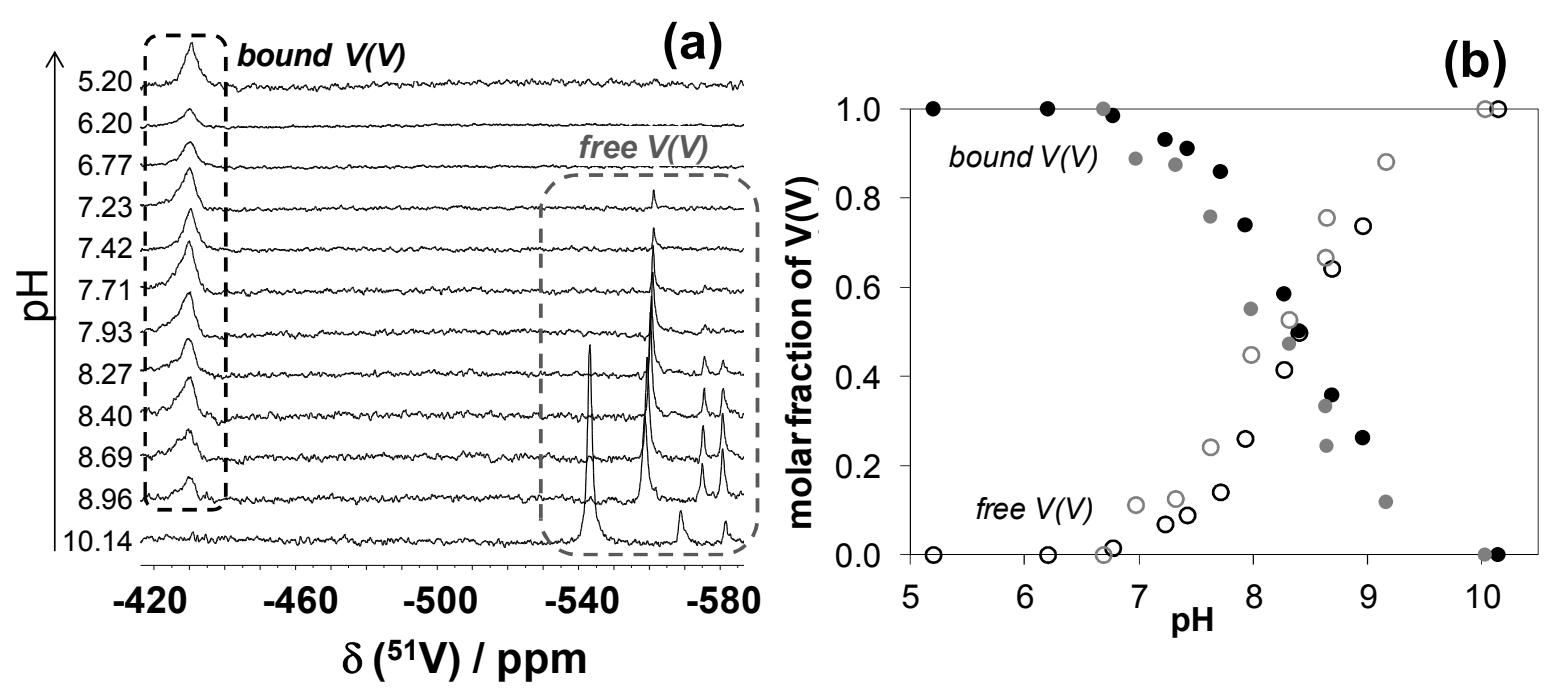

Fig. 4. ${ }^{51} \mathrm{~V}$ NMR spectra recorded for the V(V) - PTSC system at various pH values (a) and molar fractions of the non-bound vanadate (as the sum of the fractions of $\mathrm{HVO}_{4}{ }^{2-} / \mathrm{H}_{2} \mathrm{VO}_{4}{ }^{-} / \mathrm{HV}_{2} \mathrm{O}_{7}{ }^{3-} /$ $\mathrm{H}_{2} \mathrm{~V}_{2} \mathrm{O}_{7}^{2-} / \mathrm{V}_{4} \mathrm{O}_{12}{ }^{4-}$; empty circles) and bound $\mathrm{V}(\mathrm{V})$ (filled circles) for PTSC (black symbols) and APTSC (grey symbols) from the integrated area of the ${ }^{51} \mathrm{~V}$ NMR signals $(\mathrm{b}) .\left\{c_{\mathrm{V}(\mathrm{V})}=1.0 \mathrm{mM} ; \mathrm{V}(\mathrm{V}): \mathrm{L}\right.$ $=1: 1 ; T=25.0^{\circ} \mathrm{C}, I=0.10 \mathrm{M}(\mathrm{KCl})$ in $\left.30 \%(\mathrm{v} / \mathrm{v}) \mathrm{DMSO}, 60 \%(\mathrm{v} / \mathrm{v}) \mathrm{H}_{2} \mathrm{O}, 10 \%(\mathrm{v} / \mathrm{v}) \mathrm{D}_{2} \mathrm{O}.\right\}$

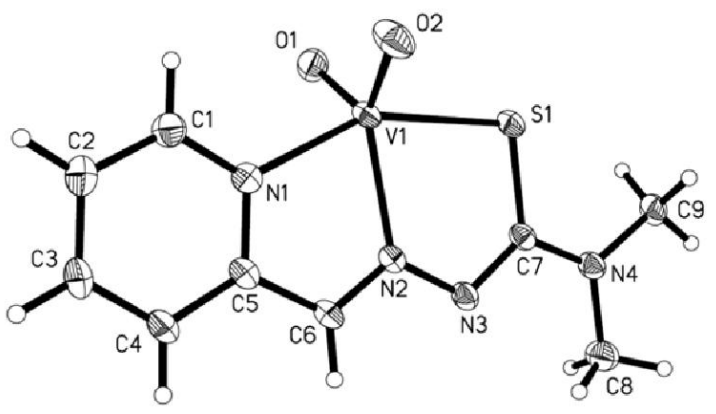

$1 \mathrm{a}$

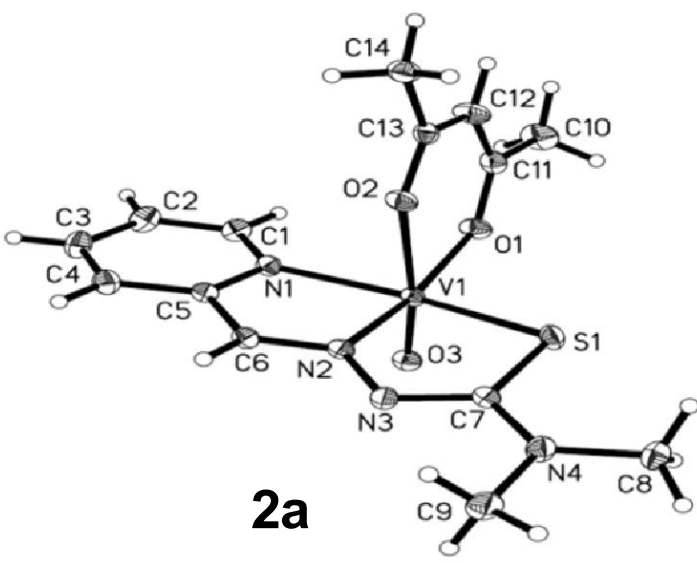

$2 \mathrm{a}$

Fig. 5. ORTEP view of $\left[\mathrm{V}(\mathrm{V}) \mathrm{O}_{2}(\mathrm{~L})\right]$ complex of PTSC (1a) and $[\mathrm{V}(\mathrm{IV}) \mathrm{O}(\mathrm{L})(\mathrm{acac})]$ complex of PTSC (2a) with thermal ellipsoids at 50\% probability level. Selected bond distances and angles are summarized in Table S2. 


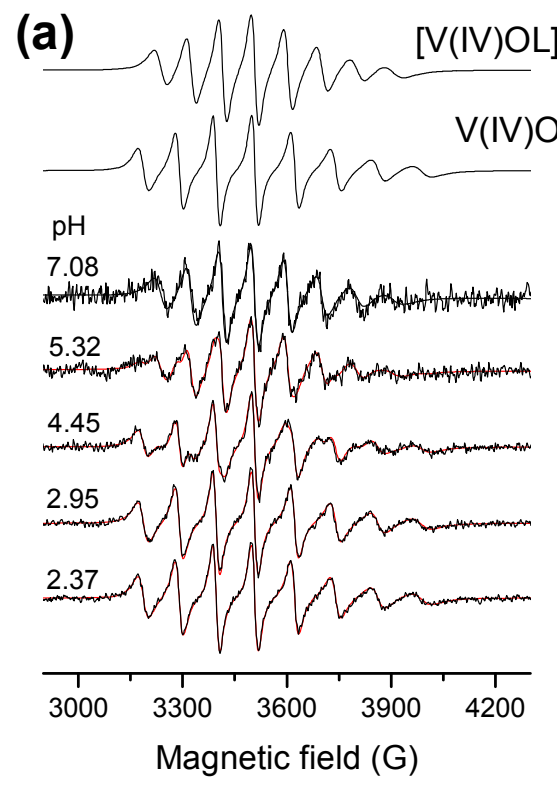

(b)

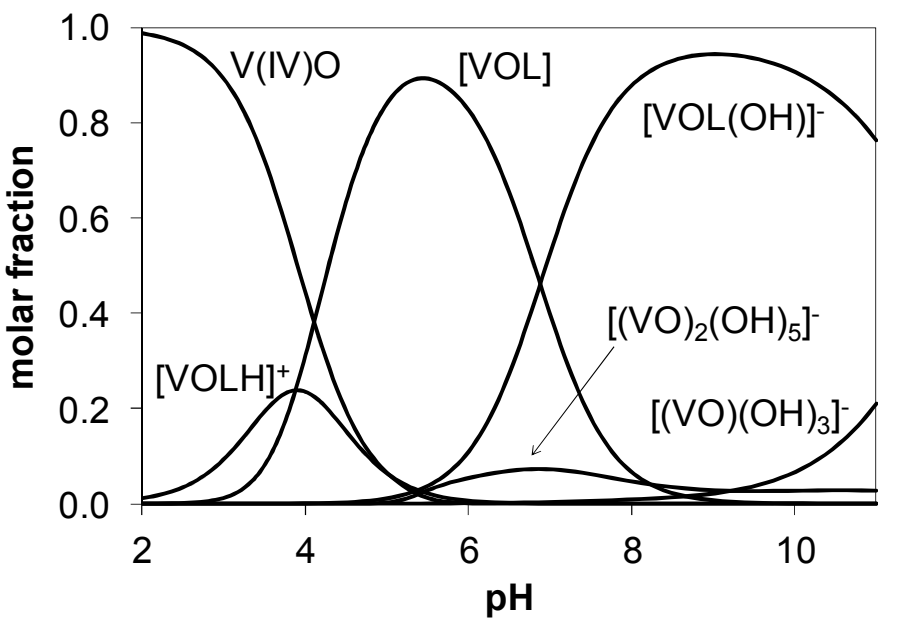

Fig. 6. Experimental (black) and simulated (red) isotropic EPR spectra recorded for the V(IV)O STSC system together with the calculated component EPR spectra of the various species with normalized spectral intensities for better comparison (a), and representative concentration distribution diagrams for $\mathrm{V}(\mathrm{IV}) \mathrm{O}$ complexes formed in the same system plotted against the $\mathrm{pH}$ calculated on the basis of the pH-potentiometric results (b) $\left\{c_{\text {ligand }}=1.0 \mathrm{mM} ; \mathrm{V}(\mathrm{IV}) \mathrm{O}: \mathrm{L}=1: 1 ; T=25.0^{\circ} \mathrm{C}, I=0.10 \mathrm{M}\right.$ $(\mathrm{KCl})$ in $30 \%(\mathrm{w} / \mathrm{w}) \mathrm{DMSO} / \mathrm{H}_{2} \mathrm{O}$. 

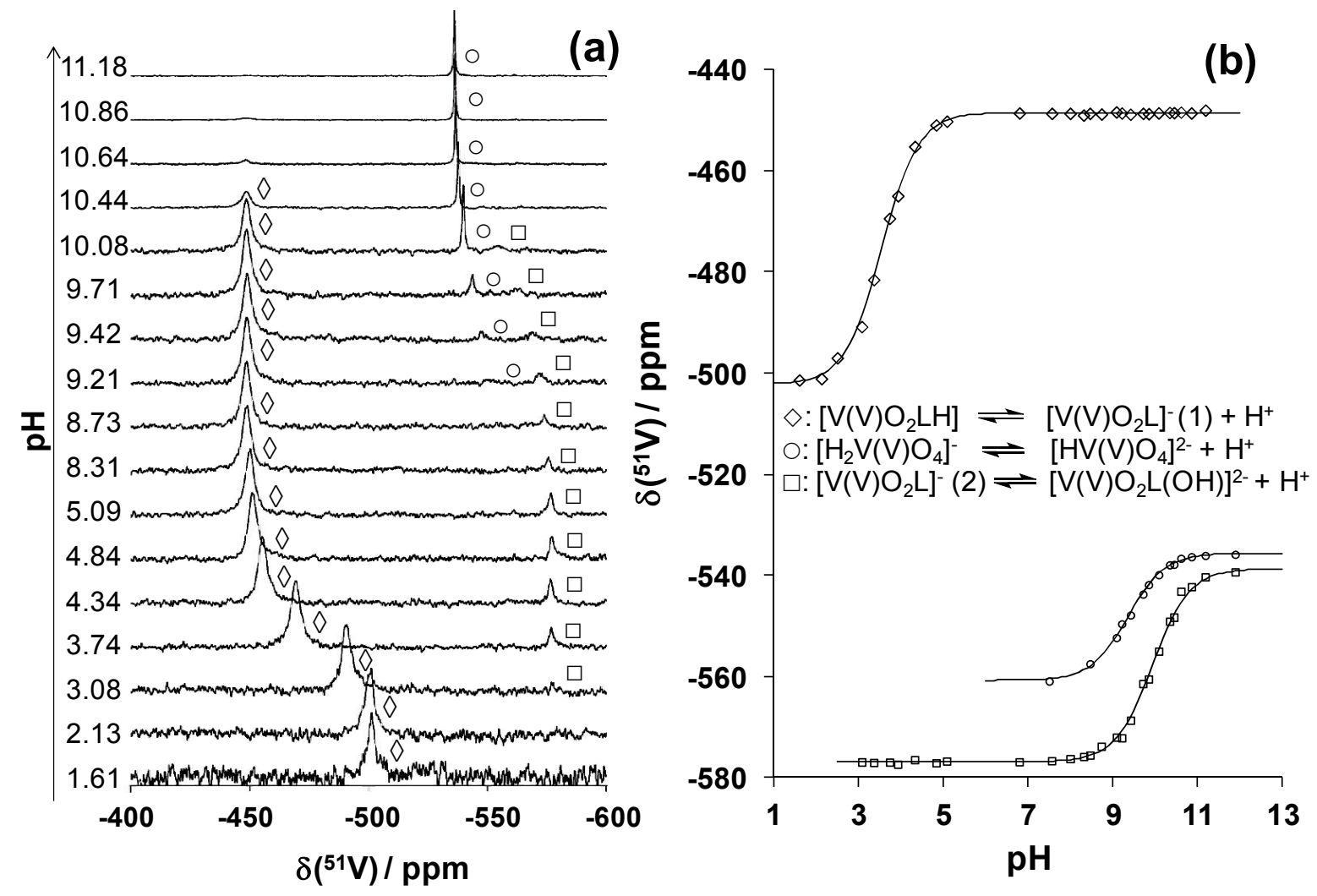

Fig. 7. ${ }^{51} \mathrm{~V}$ NMR spectra recorded for the V(V) - STSC system at various $\mathrm{pH}$ values (a) and chemical shifts of the various groups of species plotted against the $\mathrm{pH}(\mathrm{b}) . \diamond:\left[\mathrm{V}(\mathrm{V}) \mathrm{O}_{2} \mathrm{LH}\right] \rightleftharpoons\left[\mathrm{V}(\mathrm{V}) \mathrm{O}_{2} \mathrm{~L}\right]^{-}(1)$ $+\mathrm{H}^{+}$; ○: $\left[\mathrm{H}_{2} \mathrm{~V}(\mathrm{~V}) \mathrm{O}_{4}\right]^{-} \rightleftharpoons\left[\mathrm{HV}(\mathrm{V}) \mathrm{O}_{4}\right]^{2-}+\mathrm{H}^{+} ; \square:\left[\mathrm{V}(\mathrm{V}) \mathrm{O}_{2} \mathrm{~L}\right]^{-}(2) \rightleftharpoons\left[\mathrm{V}(\mathrm{V}) \mathrm{O}_{2} \mathrm{~L}(\mathrm{OH})\right]^{2-}+\mathrm{H}^{+} .\left\{c_{\mathrm{V}(\mathrm{V})}\right.$ $=1.8 \mathrm{mM} ; \mathrm{V}(\mathrm{V}): \mathrm{L}=1: 1.1 ; T=25.0^{\circ} \mathrm{C}, I=0.10 \mathrm{M}(\mathrm{KCl})$ in $30 \%(\mathrm{v} / \mathrm{v}) \mathrm{DMSO}, 60 \%(\mathrm{v} / \mathrm{v}) \mathrm{H}_{2} \mathrm{O}, 10 \%$ $\left.(\mathrm{v} / \mathrm{v}) \mathrm{D}_{2} \mathrm{O}.\right\}$

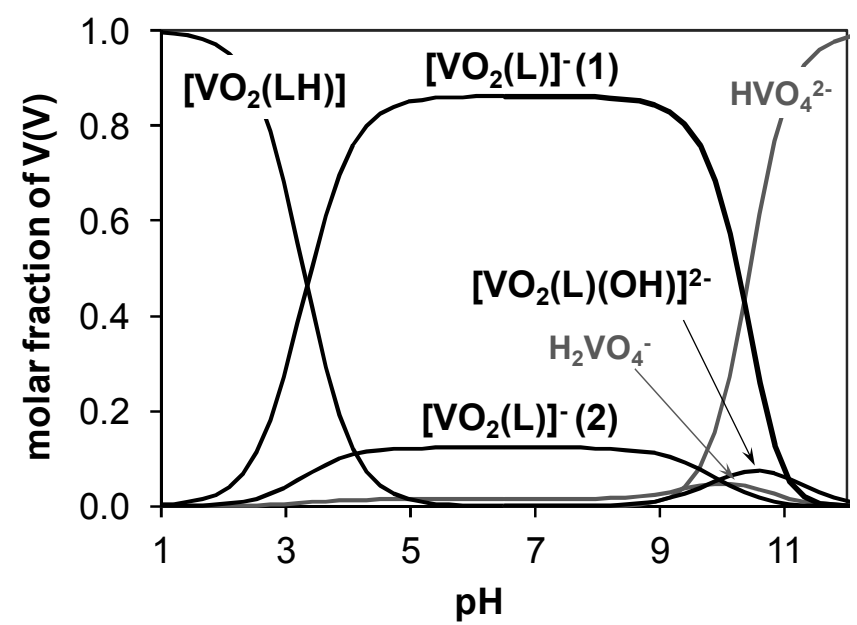

Fig. 8. Concentration distribution curves for the $\mathrm{V}(\mathrm{V})-\mathrm{STSC}$ system. $\left\{c_{\mathrm{V}(\mathrm{V})}=1.8 \mathrm{mM} ; \mathrm{V}(\mathrm{V}): \mathrm{L}=\right.$ $1: 1.1 ; T=25.0^{\circ} \mathrm{C}, I=0.10 \mathrm{M}(\mathrm{KCl})$ in $\left.30 \%(\mathrm{v} / \mathrm{v}) \mathrm{DMSO}, 60 \%(\mathrm{v} / \mathrm{v}) \mathrm{H}_{2} \mathrm{O}, 10 \%(\mathrm{v} / \mathrm{v}) \mathrm{D}_{2} \mathrm{O}.\right\}$ 
